\title{
The genus Weissella: taxonomy, ecology and biotechnological potential
}

\author{
Vincenzina Fusco ${ }^{1 *}$, Grazia M. Quero ${ }^{1}$, Gyu-Sung Cho ${ }^{2}$, Jan Kabisch ${ }^{2}$, Diana Meske ${ }^{2}$, \\ Horst Neve' ${ }^{2}$, Wilhelm Bockelmann ${ }^{2}$ and Charles M. A. P. Franz ${ }^{2}$ \\ ${ }^{1}$ National Research Council of Italy, Institute of Sciences of Food Production, Bari, Italy, ${ }^{2}$ Department of Microbiology and \\ Biotechnology, Max Rubner-Institut, Kiel, Germany
}

OPEN ACCESS

Edited by:

Michael Gänzle,

Alberta Veterinary Research Institute,

Canada

Reviewed by:

Clarissa Schwab,

Swiss Federal Institute of Technology

in Zurich, Switzerland

Katri Johanna Björkroth,

University of Helsinki, Finland

*Correspondence:

Vincenzina Fusco,

National Research Council of Italy, Institute of Sciences of Food

Production, via G. Amendola 122/o,

70126 Bari, Italy

vincenzina.fusco@ispa.cnr.it

Specialty section:

This article was submitted to Food Microbiology, a section of the journal

Frontiers in Microbiology

Received: 19 December 2014 Accepted: 10 February 2015

Published: 17 March 2015

Citation:

Fusco V, Quero GM, Cho G-S, Kabisch J, Meske D, Neve $H$, Bockelmann W and Franz CMAP

(2015) The genus Weissella:

taxonomy, ecology and

biotechnological potential.

Front. Microbiol. 6:155.

doi: 10.3389/fmicb.2015.00155
Bacteria assigned to the genus Weissella are Gram-positive, catalase-negative, non-endospore forming cells with coccoid or rod-shaped morphology (Collins et al., 1993; Björkroth et al., 2009, 2014) and belong to the group of bacteria generally known as lactic acid bacteria. Phylogenetically, the Weissella belong to the Firmicutes, class Bacilli, order Lactobacillales and family Leuconostocaceae (Collins et al., 1993). They are obligately heterofermentative, producing $\mathrm{CO}_{2}$ from carbohydrate metabolism with either $\mathrm{D}(-)$-, or a mixture of $\mathrm{D}(-)$ - and $\mathrm{L}(+)$ - lactic acid and acetic acid as major end products from sugar metabolism. To date, there are 19 validly described Weissella species known. Weissella spp. have been isolated from and occur in a wide range of habitats, e.g., on the skin and in the milk and feces of animals, from saliva, breast milk, feces and vagina of humans, from plants and vegetables, as well as from a variety of fermented foods such as European sourdoughs and Asian and African traditional fermented foods. Thus, apart from a perceived technical role of certain Weissella species involved in such traditional fermentations, specific Weissella strains are also receiving attention as potential probiotics, and strain development of particularly $W$. cibaria strains is receiving attention because of their high probiotic potential for controlling periodontal disease. Moreover, $W$. confusa and $W$. cibaria strains are known to produce copius amounts of novel, non-digestible oligosaccharides and extracellular polysaccharides, mainly dextran. These polymers are receiving increased attention for their potential application as prebiotics and for a wide range of industrial applications, predominantly for bakeries and for the production of cereal-based fermented functional beverages. On the detrimental side, strains of certain Weissella species, e.g., of $W$. viridescens, $W$. cibaria and $W$. confusa, are known as opportunistic pathogens involved in human infections while strains of $W$. ceti have been recently recongnized as etiological agent of "weissellosis," which is a disease affecting farmed rainbow trouts. Bacteria belonging to this species thus are important both from a technological, as well as from a medical point of view, and both aspects should be taken into account in any envisaged biotechnological applications.

Keywords: lactic acid bacteria, probiotic, prebiotic, bacteriocin, food safety, food quality, fermented food, detection and typing 


\section{A Brief Look at the History of Weissella Taxonomy}

Collins and colleagues were the first to designate the genus Weissella in 1993 after taxonomic studies on atypical Leuconostoc-like microorganisms which stemmed from fermented sausages produced in Greece. Collins et al. (1993) noticed that these bacteria differed from other Leuconostoc species in a number of biochemical tests. Furthermore, molecular systematic investigations suggested that leuconostocs could be separated into three distinct genetic lineages, i.e., the genus Leuconostoc sensu stricto, the L. paramesenteroides group (which included also the atypical lactobacilli) and the species then known as L. oenos (which is currently classified as Oenococcus oeni). An in-depth study based on phenotypic, biochemical and 16S rRNA gene analyses allowed the differentiation of the new genus Weissella (gen. nov.) and the re-assignment of the species previously grouped in the genus Lactobacillus as W. confusa, W. halotolerans, W. kandleri, W. minor, and $W$. viridescens. In addition, one species previously assigned to the genus Leuconostoc, i.e., W. paramesenteroides, was also included in the new genus (Collins et al., 1993).

These species, as well as a newly described, coccus-shaped isolate W. hellenica reported in the study of Collins et al. (1993), all shared high 16S rRNA gene sequence similarity, warranting them to be included into the new genus Weissella. Unusual in this respect was that all Lactobacillus species at that time were considered to be of rod shape, while species of the genus Leuconostoc were often reported as cocci. Actually, the leuconostocs do not form perfectly round cells but are rather of lentil-like shape, i.e., with tapered ends, which Collins et al. (1993) referred to as "typical irregular coccoid morphology." Nevertheless, the newly described genus Weissella comprises bacteria which are either cocci or rods in shape.

Bacteria belonging to the genus Weissella are difficult to separate from members of the genera Leuconostoc or the heterofermentative lactobacilli on the basis of phenotypic characteristics only. As mentioned above, the taxonomy of the closely related bacteria in these groups, and the new description of the genus Weissella, was possible only on the basis of molecular taxonomical techniques. The genus Weissella was named after the German microbiologist Norbert Weiss, known for his many contributions in the field of lactic acid bacteria research (Collins et al., 1993). Since the original description of the genus by Collins et al. (1993), various new species of Weissella have been described, so that currently the genus comprises 19 validated species (Figure 1). Key to these new species descriptions in the relevant studies were $16 S$ rRNA gene sequence and DNA:DNA hybridization analyses, together with phenotypic data in a polyphasic taxonomical approach. Thus, the Weissella species grouped in five phylogenetic branches based on $16 \mathrm{~S}$ phylogeny, with $W$. soli, $W$. diestrammenae, $W$. koreensis, $W$. kandleri, and $W$. oryzae as members of the first branch, W. cibaria and $W$. confusa as members of a second and $W$. thailandensis, $W$. hellenica and $W$. paramesenteroides occurring in a third branch. W. ceti, W. halotolerans, $W$. viridescens, $W$. minor, and $W$. uvarum are associated with the fourth branch, and W. beninensis, W. fabalis, W. fabaria, and W. ghanensis with the fifth (Figure 1). De Bruyne et al. (2010) showed that an improved phylogeny of Weissella based on pheS gene sequences was possible, due to the higher discriminatory power of this marker gene when compared to the 16S rRNA gene. Based on the pheS phylogenetic investigation (Figure 1), the authors showed that the new species described in that study as $W$. fabaria, together with the then already described $W$. ghanensis species clustered together as a first divergent line within the genus Weissella. Subsequent to the study of De Bruyne et al. (2010), two further novel species, i.e., $W$. beninensis and $W$. fabalis were described (Padonou et al., 2010; Snauwaert et al., 2013) that also grouped together with $W$. fabaria and $W$. ghanensis into a welldefined cluster. Thus, these four species appear to constitute this first divergent line of species within the genus Weissella. The term "species groups" has been previously used to group species that occur in phylogenetically closely related groups as in the case, e.g., for the enterococci (Švec and Franz, 2014). This has so far not been done for species occurring in the genus Weissella. Based on the clear grouping of species into 5 well-defined clusters, these groups could be designated as the $W$. kandleri, W. confusa, $W$. halotolerans, $W$. paramesenteroides, and $W$. beninensis species groups, respectively.

\section{General Description of Bacteria Belonging to the Genus Weissella}

Bacteria belonging to the genus Weissella are Gram-positive, catalase-negative, non-endospore forming cells with coccoid or rod-shaped morphology (Collins et al., 1993; Björkroth et al., 2009, 2014). The Weissella species belong to the phylum Firmicutes, class Bacilli, order Lactobacillales and family Leuconostocaceae (Collins et al., 1993). Only W. beninensis was reported to be motile (Padonou et al., 2010), with all other species being non-motile. As in the original description of the genus Weissella (Collins et al., 1993), the bacteria of this genus were described to be non-motile, this motile characteristic of $W$. beninensis is not in accordance with the description of general characteristics of bacteria in this genus, and consequently the genus description was emended by Padonou et al. (2010) to account for atypical motility of this particular species. Weissella bacteria are facultatively anaerobic chemoorganotrophs with an obligately fermentative metabolism. They do not possess cytochromes and ferment glucose heterofermentatively via the hexose-monophosphate and phosphoketolase pathways. End products of glucose heterofermentation include lactic acid (with some species producing only $\mathrm{D}(-)$ and others both $\mathrm{D}(-)$ and $\mathrm{L}(+)$ lactic acid enantiomers), gas $\left(\mathrm{CO}_{2}\right)$ and ethanol and/or acetate (Collins et al., 1993; Björkroth et al., 2014). The bacteria have complex nutritional requirements and need peptides, amino acids, fermentable carbohydrates, nucleic acids, fatty acids and vitamins for growth. All species grow at $15^{\circ} \mathrm{C}$ and some can grow up to $42-45^{\circ} \mathrm{C}$. Production of dextran, hydrolysis of esculin and production of ammonia from arginine are variable characteristics for the different species, and may be used as phenotypic tests to aid in species identification (Table 1). The same applies for fermentation of sugars such as cellobiose, fructose, galactose, lactose, maltose, melibiose, raffinose, ribose, sucrose, trehalose and xylose (Table 1). The cell wall 


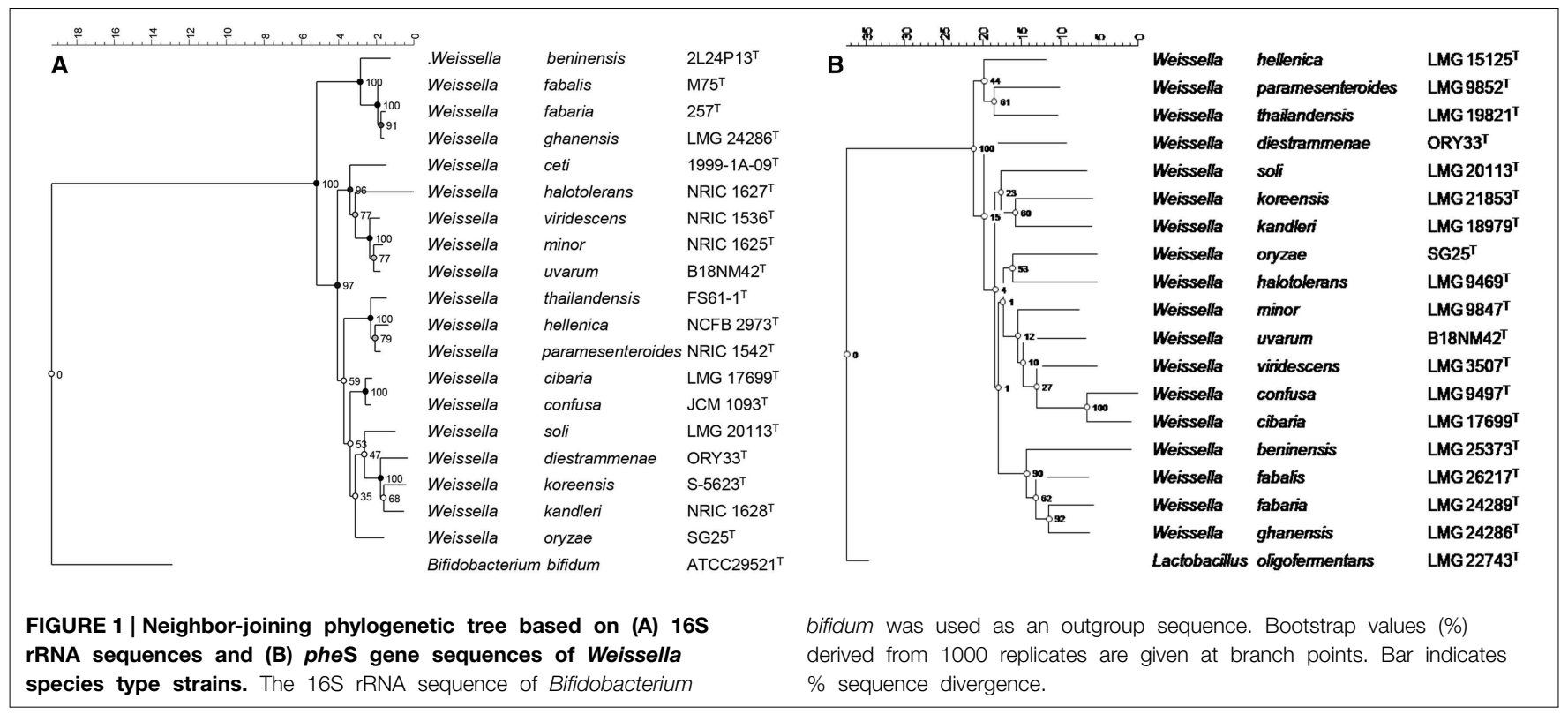

TABLE 1 | Differential characteristics of Weissella species.

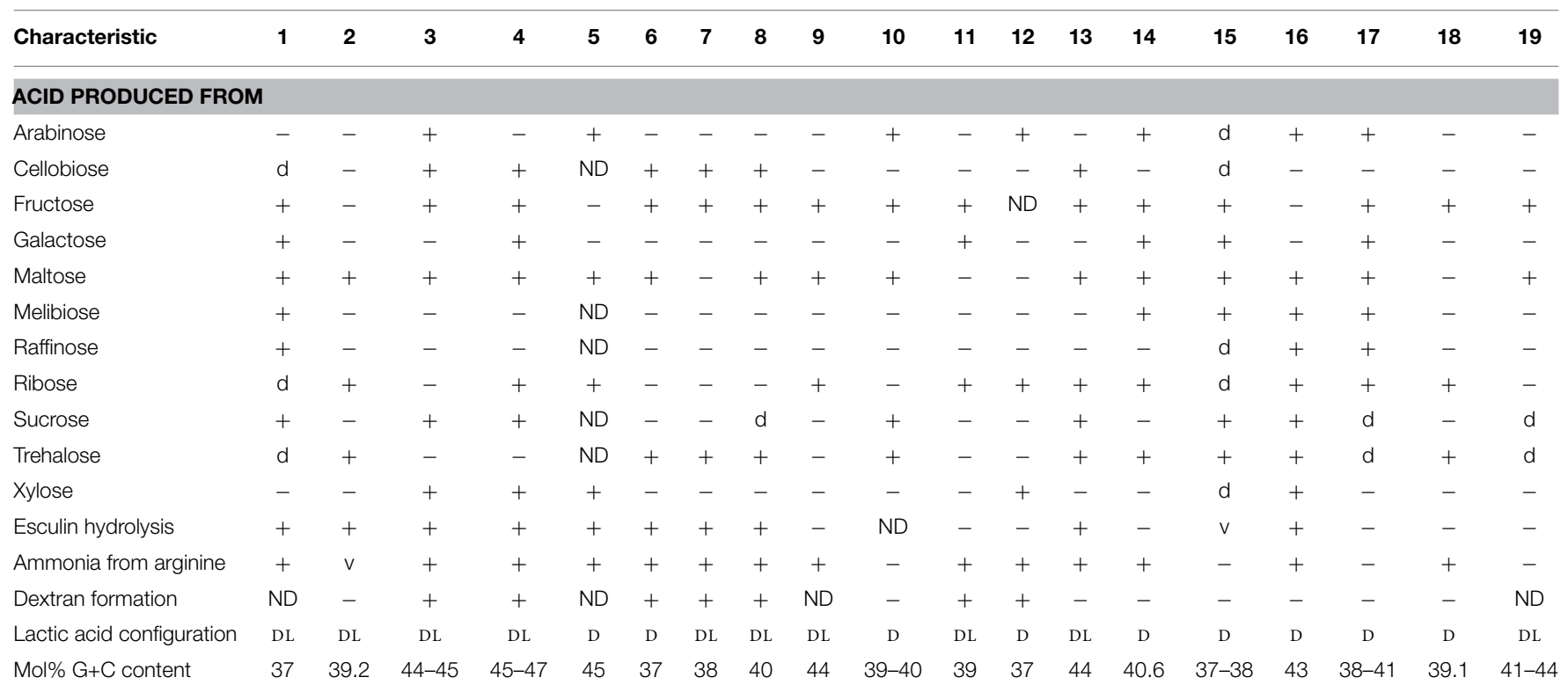

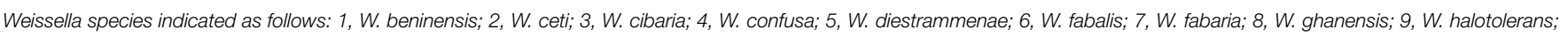
10, W. hellenica; 11, W. kandleri; 12, W. koreensis; 13, W. minor; 14, W. oryzae; 15, W. paramesenteroides; 16, W. soli; 17, W. thailandensis; 18, W. uvarum; 19, W. viridescens. ,$+ 90 \%$ or more strains are positive; -, 90\% or more strains negative; $d, 11-89 \%$ of strains positive; ND, no data available; $v$, variable.

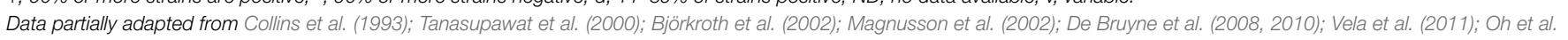
(2013); Snauwaert et al. (2013); Tohno et al. (2013) and Nisiotou et al. (2014).

peptidoglycan is based on lysine as the diamino acid and, apart from $W$. kandleri, all contain alanine or alanine and serine in the interpeptide bridge (Björkroth et al., 2009). The interpeptide bridge of W. kandleri contains glycine (Holzapfel and van Wyk, 1982; Björkroth et al., 2009). The mol\% G+C content of the different Weissella species ranges between 37 and $47 \%$, which is close to the recommended $10 \%$ that should not be exceeded for genus definition (Stackebrandt and Liesack, 1993).

\section{Ecology}

Bacteria of the genus Weissella inhabit a variety of ecological niches, including soil (mainly W. soli) (Magnusson et al., 2002; Chen et al., 2005), sludge of milking machines (W. minor) (Kandler et al., 1983), sediments of a coastal marsh (W. cibaria and $W$. confusa) (Zamudio-Maya et al., 2008), sediments and fish from the Bahía Blanca estuary (W. viridescens) (Sica et al., 
2010) and lake water (W. cibaria) (Yanagida et al., 2007), plants (Table 2), a huge variety of fermented foods (Table 3), the oral cavity, breast milk, the uro-genital and gastro-intestinal tracts of humans (Table 4), as well as the skin, milk and gastro-intestinal tract of many animals (Table 5).

Typical for lactic acid bacteria, to which the Weissella spp. belong, is their association with and adaptation to nutrient rich habitats (Makarova et al., 2006) including various food sources. Some Weissella species, i.e., W. viridescens, W. halotolerans, and $W$. hellenica, are mainly associated with meat and meat products, and were reported as part of the predominant microbiota responsible for quality fluctuations of packaged and chill-stored food products (Pothakos et al., 2014). Similarly, W. halotolerans has been reported to predominate in the microbial spoilage population of vacuum-packaged, charcoal-broiled European river lamprey (Lampetra fluviatilis) (Merivirta et al., 2005). W. viridescens causes spoilage of cured meats due to a green discoloration (Niven and Evans, 1957) and is involved in spoilage of the Spanish blood sausage Morcilla de Burgos (Santos et al., 2005; Koort et al., 2006; Diez et al., 2009) and of vacuum-packaged cooked sausages (Korkeala and Björkroth, 1997; Iacumin et al., 2014).

Weissella species are also commonly found in habitats associated with the human or animal body, e.g., the gastrointestinal tract or in human breast milk. W. cibaria was found to be present in all fecal samples from healthy adults, but less frequent in the fecal samples of celiac disease patients (Nistal et al., 2012).
$W$. confusa was shown to be more widely distributed in the feces of non-irritable bowel syndrome patients than in the feces of patients affected by this disease (Ponnusamy et al., 2011). High loads of Weissella spp. were also found in the ileal microbiota of piglets fed with different amounts of zinc oxide $(\mathrm{ZnO})$, an amphoteric molecule that is widely used as feed additive for the prophylaxis of diarrhea in piglets (Vahjen et al., 2010). W. confusa was found in the breast milk, as well as in the feces of both mothers and infants (Martín et al., 2007a,a; Albesharat et al., 2011), confirming the hypothesized mechanism of vertical transfer from the mother's gut to the corresponding milk and subsequently from the milk to the infant's gut. Regarding the presence of Weissella and other microorganisms in human milk, possible mechanisms by which these bacteria can reach the mammary gland (i.e., either by contamination or by active migration) have been reviewed recently (Jeurink et al., 2013). It has been suggested (Lahtinen et al., 2012) that Weissella strains from human milk, stem from an environmental source (e.g., soil, vegetation). Indeed, the mode of delivery at birth, the kind of diet, as well as the health status of humans and animals may affect the composition of the microbiota of the oral cavity, the gastro-intestinal and uro-genital tracts. In agreement with this, by using a highthroughput sequencing approach, Belda et al. (2011) could show that $W$. paramesenteroides occurs at notably higher levels in the midgut of lab-reared populations of the European Corn Borer Ostrinia nubilalis than in the field population, in which gramnegative species were found to predominate. This probably was

TABLE 2 | Occurrence of Weissella species in different environmental habitats.

\begin{tabular}{|c|c|c|}
\hline Species & Habitat or Source & References \\
\hline \multirow[t]{8}{*}{ W. cibaria } & Japanese horseradish, orange, pineapple, banana, chili bo & Endo et al., 2009 \\
\hline & Tomatoes & Di Cagno et al., 2009a \\
\hline & Fluted pumpkin vegetable (Telfairia occidentalis) and green vegetable (Amaranthus spinosus) & Emerenini et al., 2014 \\
\hline & Bee pollen & Belhadj et al., 2014 \\
\hline & Wheat flour & Alfonzo et al., 2013 \\
\hline & Corn stovers & Pang et al., 2011 \\
\hline & Blackberries & Di Cagno et al., 2011 \\
\hline & Papaya & Di Cagno et al., 2011 \\
\hline \multirow[t]{4}{*}{ W. confusa } & Rhizosphere of olive trees, soil surrounding rhizospere & Fhoula et al., 2013 \\
\hline & Raw red and yellow pepper & Di Cagno et al., 2009b \\
\hline & Heroin & Cho et al., 2014 \\
\hline & Sugar cane and carrot juice & Hammes and Vogel, 1995 \\
\hline W. halotolerans & Rhizosphere of olive tree, soil surrounding rhizospere & Fhoula et al., 2013 \\
\hline W. hellenica & Vegetative forage crops (mixed pasture of timothy and orchardgrass) & Tohno et al., 2012 \\
\hline W. hellenica & Heroin & Cho et al., 2014 \\
\hline W. kandleri & Desert spring and desert plants & Holzapfel and van Wyk, 1982 \\
\hline W. kimchii (W. cibaria) & Fluted pumpkin vegetable (Telfairia occidentalis) and green vegetable (Amaranthus spinosus) & Emerenini et al., 2014 \\
\hline \multirow[t]{5}{*}{ W. paramesenteroides } & Rhizosphere of olive trees & Fhoula et al., 2013 \\
\hline & Fluted pumpkin vegetable (Telfairia occidentalis) and green vegetable (Amaranthus spinosus) & Emerenini et al., 2014 \\
\hline & Chardonnay grapes, Semillon and Sauvignon Blanc grapes & Bae et al., 2006 \\
\hline & Indian goosegrass & Pang et al., 2012 \\
\hline & Vegetative forage crops (mixed pasture of timothy and orchardgrass) & Tohno et al., 2012 \\
\hline W. soli & Carrots & Di Cagno et al., 2008 \\
\hline
\end{tabular}


TABLE 3 | Isolation of Weissella species from (fermented) foods.

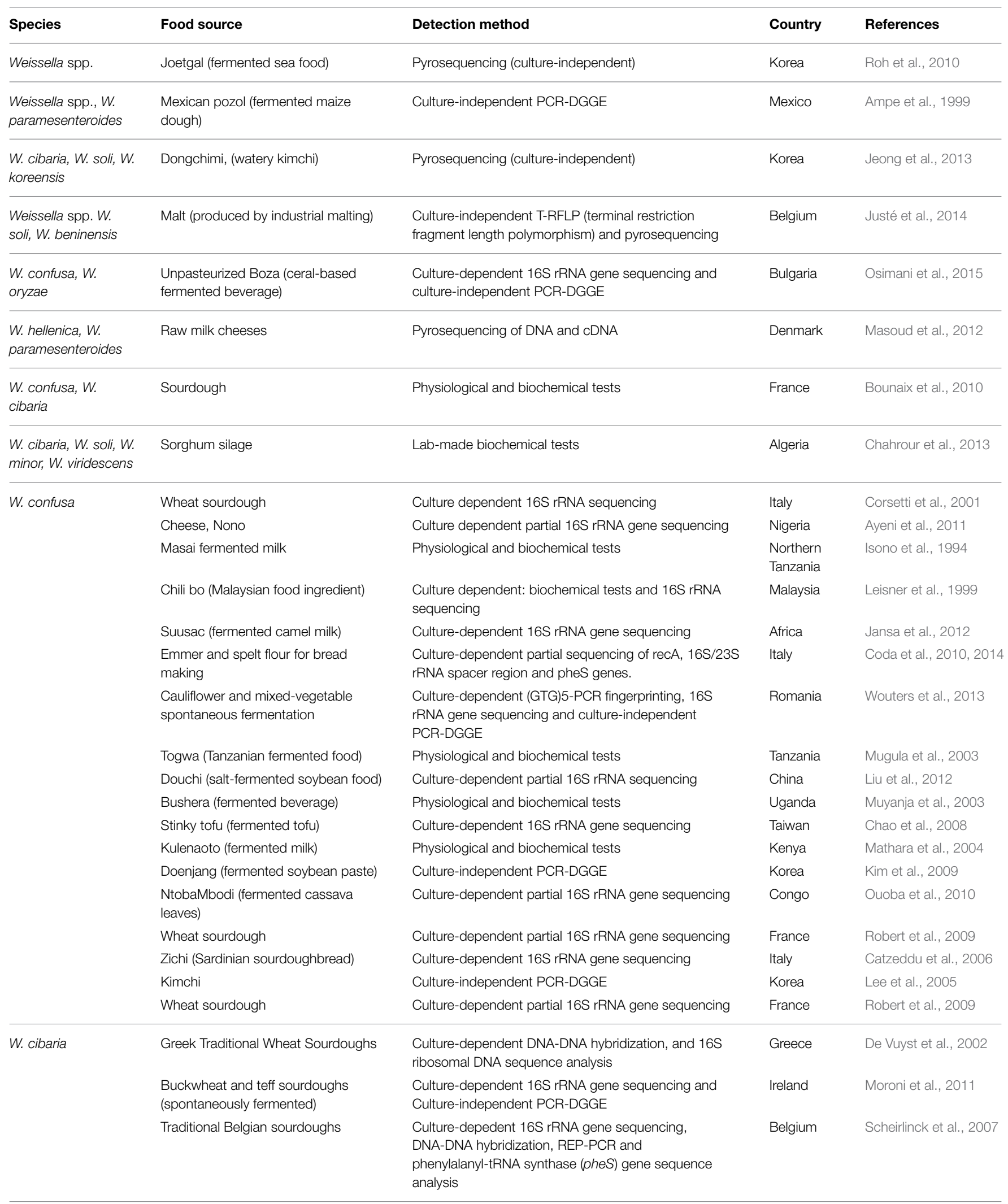




\section{TABLE 3 | Continued}

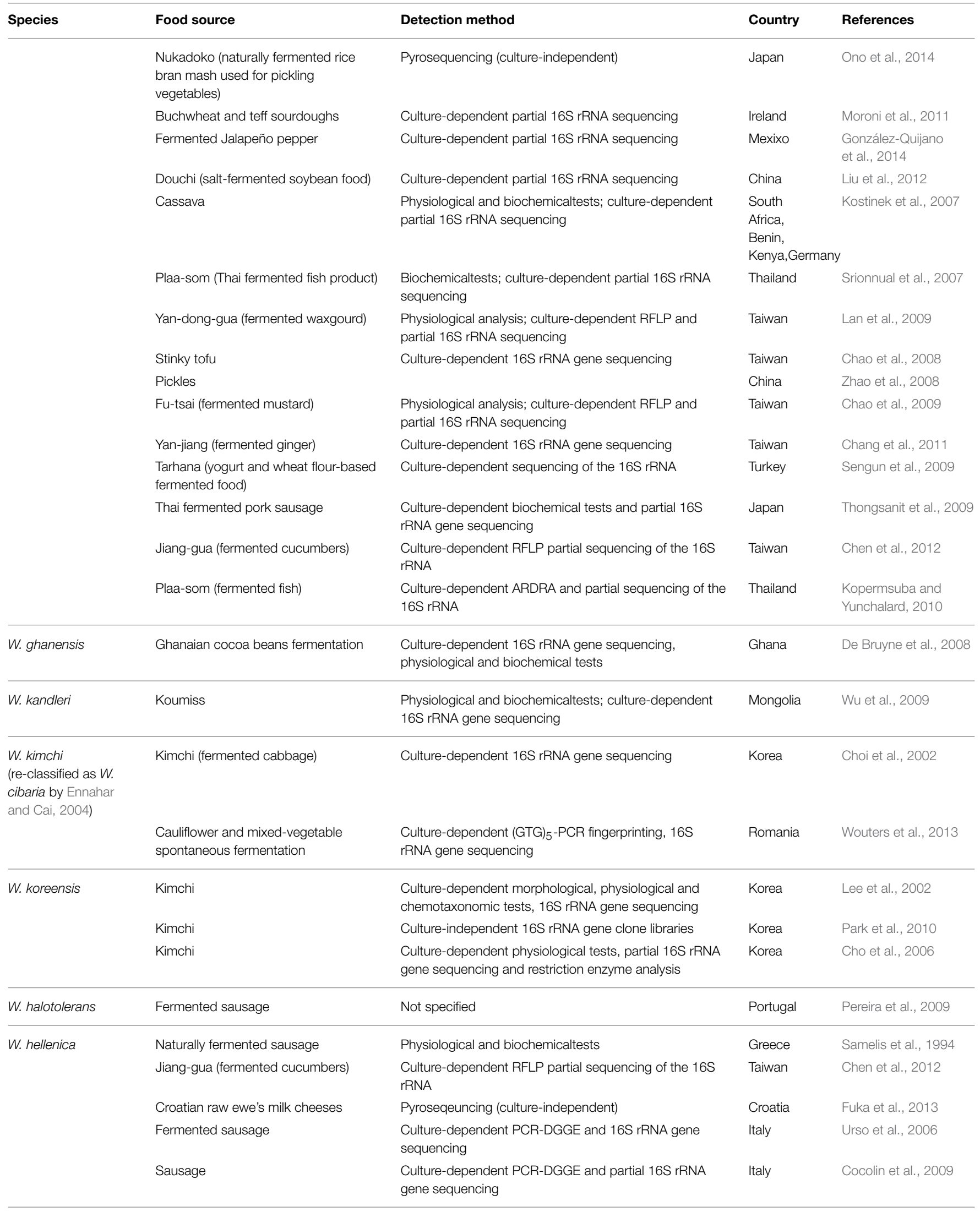




\section{TABLE 3 | Continued}

\begin{tabular}{|c|c|c|c|c|}
\hline Species & Food source & Detection method & Country & References \\
\hline \multirow[t]{2}{*}{ W. minor } & Gari (fermented cassava) & $\begin{array}{l}\text { Physiological and biochemical tests; culture-dependent } \\
\text { partial } 16 \text { S rRNA sequencing }\end{array}$ & Africa & Kostinek et al., 2005 \\
\hline & sludge of milking machines & 16S rRNA gene sequencing, DNA-DNA hybridization & Germany & Kandler et al., 1983 \\
\hline \multirow[t]{10}{*}{$\begin{array}{l}\text { W. paramesen- } \\
\text { teroides }\end{array}$} & Fermented sausage & $\begin{array}{l}\text { Culture-dependent PCR-DGGE and 16S rRNA gene } \\
\text { sequencing }\end{array}$ & Italy & Urso et al., 2006 \\
\hline & Goat's milk cheese & API $50 \mathrm{CH}$ and API 20 STREP systems (BioMerieux) & Spain & Mas et al., 2002 \\
\hline & Joetgal (fermented sea food) & Culture-independent PCR-DGGE & Korea & Roh et al., 2010 \\
\hline & $\begin{array}{l}\text { Nukadoko (naturally fermented rice } \\
\text { bran mash used for pickling } \\
\text { vegetables) }\end{array}$ & Pyrosequencing (culture-independent) & Japan & Ono et al., 2014 \\
\hline & Douchi (salt-fermented soybean food) & Culture-dependent partial 16S rRNA sequencing & China & Liu et al., 2012 \\
\hline & Croatian raw ewe's milk cheeses & Pyrosequencing (culture-independent) & Croatia & Fuka et al., 2013 \\
\hline & Yan-dong-gua (fermented waxgourd) & $\begin{array}{l}\text { Culture-dependent PCR-DGGE and 16S rRNA gene } \\
\text { sequencing }\end{array}$ & Taiwan & Lan et al., 2009 \\
\hline & Stinky tofu & $\begin{array}{l}\text { Culture-dependent PCR-DGGE and partial 16S rRNA } \\
\text { gene sequencing }\end{array}$ & Taiwan & Chao et al., 2008 \\
\hline & Fu-tsai & $\begin{array}{l}\text { Culture-dependent partial sequencing of the } 16 \mathrm{~S} \text { rRNA, } \\
\text { rpoA, pheS and dnaA genes }\end{array}$ & Taiwan & Chao et al., 2009 \\
\hline & Cassava & $\begin{array}{l}\text { Culture-dependent physiological and biochemical tests, } \\
\text { partial } 16 \mathrm{~S} \text { rRNA gene sequencing }\end{array}$ & $\begin{array}{l}\text { South Africa, } \\
\text { Benin, Kenya, } \\
\text { Germany }\end{array}$ & Kostinek et al., 2007 \\
\hline W. soli & Stinky tofu & $\begin{array}{l}\text { Culture-dependent phenotypic and chemotaxonomic } \\
\text { tests, partial 16S rRNA gene sequencing }\end{array}$ & Taiwan & Chao et al., 2008 \\
\hline W. taj-apis ${ }^{a}$ & Honey & 16S rRNA gene sequencing & Malaysia & Tajabadi et al., 2012 \\
\hline W. thailandensis & Pla-ra and pla-chom (fermented fish) & $\begin{array}{l}\text { Phenotypic and chemotaxonomic tests; } \\
\text { culture-dependent partial } 16 \mathrm{~S}\end{array}$ & Thailand & $\begin{array}{l}\text { Tanasupawat et al., } \\
\text { 1998, } 2000\end{array}$ \\
\hline \multirow[t]{4}{*}{ W. viridescens } & Dry-fermented sausage & & Greece & Papamanoli et al., 2003 \\
\hline & $\begin{array}{l}\text { Cauliflower and mixed-vegetable } \\
\text { spontaneous fermentation }\end{array}$ & $\begin{array}{l}\text { Culture-dependent (GTG)5-PCR fingerprinting, } 16 \mathrm{~S} \\
\text { rRNA gene sequencing }\end{array}$ & Romania & Wouters et al., 2013 \\
\hline & Nham (Thai-fermented pork sausage) & $\begin{array}{l}\text { Culture-dependent physiological and biochemical tests, } \\
16 \mathrm{~S} \text { rRNA gene sequencing }\end{array}$ & Thailand & Pringsulaka et al., 2011 \\
\hline & Doenjang (fermented soy bean paste) & Culture-independent PCR-DGGE & Korea & Kim et al., 2009 \\
\hline W. uvarum & Wine grapes & 16S rRNA gene sequencing, DNA-DNA hybridization & Greece & Nisiotou et al., 2014 \\
\hline
\end{tabular}

a Weissella taj-apisdescribed by Tajabadi et al. (2012) is currently an unvalidated species description.

the result of an increase in cell numbers due to the multiplication of these bacteria in the artificial diet prior to insect feeding. This finding led to the hypothesis that food exerts a selection pressure on the intestinal microbiota (Belda et al., 2011).

\section{Weissella Strains Associated with Human Clinical Infections}

Weissella strains have been isolated from clinical specimens such as blood, skin, infected wounds and feces of both humans and animals (Table 6). Apart from Kulwichit et al. (2007), who identified a Weissella strain from the blood of a patient as W. viridescens, and others from urine, lung swabs and blood of patients with bacteremia as $W$. cibaria, the only species of Weissella, which have been described as opportunistic pathogens of humans or as emerging pathogen for farmed rainbow trouts are $W$. confusa and W. ceti, respectively. In particular, W. confusa was isolated from several human and clinical specimens in cases of polymicrobial infections (Green et al., 1990, 1991; Riebel and Washington, 1990; Bantar et al., 1991; Olano et al., 2001; Björkroth et al., 2002). The isolation of the strains from polymicrobial infections did not allow an unequivocal clinical significance of this species. Subsequently, however, this species was also described as sole microbial agent in various infections which allowed the description of $W$. confusa as an opportunistic pathogen. Indeed, $W$. confusa was the causative agent of infections such as a systemic infection in a mona monkey (Cercopithecus mona) (Vela et al., 2003), a fatal case of endocarditis (Flaherty et al., 2003), a severe infective endocarditis of native valves (Shin et al., 2007), a postoperative osteomyelitis with chronic discharge in a young female (Kulwichit et al., 
TABLE 4 | Weissella species in saliva, feces and vagina of humans.

\begin{tabular}{|c|c|c|}
\hline Species & Habitat or Source & References \\
\hline \multirow[t]{5}{*}{ W. cibaria } & Children's saliva (4-7 years old) & Kang et al., 2006a,b \\
\hline & Human saliva & Kang et al., 2011 \\
\hline & Human feces & Wang et al., 2008 \\
\hline & & Nistal et al., 2012 \\
\hline & Human vagina & Nam et al., 2007 \\
\hline \multirow[t]{4}{*}{ W. confusa } & Human faecis & Ponnusamy et al., 2011 \\
\hline & $\begin{array}{l}\text { Human feces (adults, mothers } \\
\text { and babies) }\end{array}$ & Albesharat et al., 2011 \\
\hline & Human feces & Zhang et al., 2014 \\
\hline & & Walter et al., 2001 \\
\hline \multirow{3}{*}{$\begin{array}{l}\text { W. confusa } \\
\text { and W. Cibaria }\end{array}$} & Human feces & Gomathi et al., 2014 \\
\hline & & $\begin{array}{l}\text { Chun et al., 2007; Lee } \\
\text { et al., } 2012\end{array}$ \\
\hline & $\begin{array}{l}\text { Breast milk, vaginal swab and } \\
\text { infant feces }\end{array}$ & Martín et al., 2007a,b \\
\hline \multirow{2}{*}{$\begin{array}{l}\text { W. kimchii (W. } \\
\text { cibaria) }\end{array}$} & Human vagina & Lee, 2005 \\
\hline & Human vagina & Jin et al., 2007 \\
\hline $\begin{array}{l}\text { W. paramesen- } \\
\text { teroides }\end{array}$ & Feces of breast-fed infants & Rubio et al., 2014 \\
\hline \multirow[t]{2}{*}{ W. viridescens } & Human vagina & $\begin{array}{l}\text { Silvester and Dicks, } \\
2003\end{array}$ \\
\hline & & Jin et al., 2007 \\
\hline
\end{tabular}

2008), and a sepsis in a 48-year-old male who was operated for adenocarcinoma of the gastro-oesophageal junction and who was maintained on a total parenteral nutrition (Kumar et al., 2011). Furthermore, it also caused infection in patients with hepatocellular carcinoma occurring after liver transplant (Harlan et al., 2011), in patients with acute lymphocytic leukemia undergoing autologous stem cell transplantion (Salimnia et al., 2011), and in a patient with a prostetic joint infection (Medford et al., 2014). A large case series (i.e., a descriptive study that follows a group of patients who have a similar diagnosis or who are undergoing the same procedure over a certain period of time; http://jbjs.org/content/91/Supplement_3/21), was reported by Lee et al. (2011) and involved 10 patients with bacteremia. Risk factors for invasive infection in this group included a central line catheter insertion, a concurrent polymicrobial bacteremia and an immunocompromised host, together with gastrointestinal manipulation through endoscopy, or surgery that may have allowed the contamination of Weissella into the blood stream. Indeed, as highlighted by Medford et al. (2014), most cases of clinical infection with Weissella were associated with medical procedures within the period of infection. W. confusa was also found to cause neonatal sepsis in a foal (Lawhon et al., 2014). $W$. ceti has recently been recognized as the etiological agent of
TABLE 5 | Weissella species in healthy animals' milk and skin.

\begin{tabular}{lll}
\hline Species & Habitat or Source & References \\
\hline $\begin{array}{l}\text { Weissella } \\
\text { spp. }\end{array}$ & Ewe's milk & Aquilanti et al., 2007 \\
\cline { 2 - 3 } & $\begin{array}{l}\text { lleal digesta of piglets fed diets } \\
\text { supplemented with 200 or } \\
\text { 3000 ppm ZnO }\end{array}$ & Vahjen et al., 2010 \\
\end{tabular}

\begin{tabular}{lll}
\hline W. cibaria & Camel's milk & Merzouk et al., 2013 \\
& Goat's milk & Elavarasi et al., 2014 \\
& Feces of individually (healthy) & Graef et al., 2005
\end{tabular}

owned dogs

Acquatic animals Muñoz-Atienza et al., 2013

Feces of farmed Atlantic salmon Hovda et al., 2012

(Salmo salar L.)

Gastro-intestinal tract of brown Abid et al., 2013

trout

Human feces and human gall, $\quad$ Björkroth et al., 2002

Canary liver

\begin{tabular}{|c|c|c|}
\hline \multirow[t]{4}{*}{ W. confusa } & Cow's milk & Zambou et al., 2008 \\
\hline & Cow's intestine & Ayeni et al., 2011 \\
\hline & $\begin{array}{l}\text { Intestines of adult farmed } \\
\text { seabass (Lates calcarifer) }\end{array}$ & Sirirat et al., 2008 \\
\hline & $\begin{array}{l}\text { Intestines of farmed Asian } \\
\text { seabass (Lates calcarifer) }\end{array}$ & Rengpipat et al., 2008 \\
\hline $\begin{array}{l}\text { W. confusa } \\
\text { and } W . \\
\text { cibaria }\end{array}$ & Canine feces & Beasley et al., 2006 \\
\hline $\begin{array}{l}\text { W. diestram- } \\
\text { menae }\end{array}$ & Gut of a camel cricket & Oh et al., 2013 \\
\hline \multirow[t]{2}{*}{ W. hellenica } & Cow's milk & Masoud et al., 2012 \\
\hline & $\begin{array}{l}\text { Intestinal contents of flounder } \\
\text { (Paralichthys olivaceus) }\end{array}$ & Cai et al., 1998 \\
\hline
\end{tabular}

\begin{tabular}{lll}
\hline $\begin{array}{l}\text { W. parame- } \\
\text { senteroides }\end{array}$ & Cow's milk & Espeche et al., 2009 \\
& $\begin{array}{l}\text { Distal gut contents of rainbow } \\
\text { trout fed different plant based } \\
\text { diets }\end{array}$ & Desai et al., 2012 \\
\hline $\begin{array}{l}\text { W. viri- } \\
\text { descens }\end{array}$ & Canine milk & Martín et al., 2010 \\
\hline $\begin{array}{l}\text { W. parame- } \\
\text { sentroides }\end{array}$ & Midgut of Ostrinia nubilalis & Belda et al., 2011
\end{tabular}

the so-called "weissellosis" (Welch et al., 2014), an emergent disease occurring in farmed rainbow trout (Oncorhynchus mykiss) causing septicemia with a high mortality rate (Costa et al., 2015). Weissellosis outbreaks have been reported from commercial trout farms in the United States, China and Brazil (Liu et al., 2009; Figueiredo et al., 2012; Welch and Good, 2013; Costa et al., 2015). Symptoms of this disease include lethargy and anorexia, extensive ocular lesions, occasional cerebral hemorrhage and dark skin coloration (Welch et al., 2014). Apparently, high summer 
temperatures seems to be the main predisposing factor for this emerging disease that appears to affect only the large-size fishes $(0.5-1 \mathrm{~kg})$ in a trout farm, while ongoing studies are focusing on ascertaining the pathogen's route of infection and its reservoirs (Welch et al., 2014).

As suggested by several authors (Lahtinen et al., 2012; Fairfax et al., 2014; Medford et al., 2014), infections caused by Weissella, as those caused by Leuconostoc, are mainly due to their natural vancomycin resistance, and usually occur in cases of immunosuppression or underlying disease of the host. However, infections caused by Weissella spp. are generally rare, although an underestimation may occur as a result of the inability of commercial bacterial identification systems [such as the API $50 \mathrm{CHL}$ kit (BioMérieux, Lyon, France) etc.] in identifying these bacteria as they closely resemble viridans streptococci (Fairfax et al., 2014).

\section{Potentially Probiotic or Technologically Uses of Weissella Strains}

In several studies, Weissella strains were screened for antimicrobial activity (Nam et al., 2002; Pal et al., 2010; Ndagano et al., 2011; Papagianni and Papamichael, 2011; Masuda et al., 2012; Papagianni, 2012; Vitali et al., 2012; Leong et al., 2013; Papagianni and Sergelidis, 2013; Serna-Cock et al., 2013; Yoshiyama et al., 2013; Emerenini et al., 2014). Six bacteriocins have so far been reported for Weissella strains belonging to the W. cibaria, $W$. paramesenteroides, and W. hellenica species (Table 7). Among these, the listericidal bacteriocin weissellin A was further investigated for its technological application in fermented sausages (Papagianni, 2012; Papagianni and Papamichael, 2012; Papagianni and Sergelidis, 2013), while the bacteriocinogenic W. hellenica strain D1501 was successfully used to enhance the shelf-life of tofu (Chen et al., 2014b).

Aiming at developing novel probiotic foods or probiotic animal feeds, many researchers have isolated and screened Weissella strains from humans (Ayeni et al., 2011; Lee et al., 2012; Gomathi et al., 2014; Zhang et al., 2014), animal feces (Cai et al., 1998; Beasley et al., 2006; Muñoz-Atienza et al., 2013) as well as from a variety of food matrices, including vegetable, fruits, cured meat and dairy matrices, for their probiotic potential (Papamanoli et al., 2003; Vitali et al., 2012; Patel et al., 2013; Yoshiyama et al., 2013; Yang et al., 2014). However, only few studies investigated the probiotic potential of Weissella strains using in vivo studies. Wang et al. (2011) demonstrated that dietary supplementation with fermented garlic together with $W$. koorensis in growing pigs can improve the average daily gain and has a positive impact on the immune response during an inflammatory challenge (Wang et al., 2011). W. cibaria isolates from children's saliva were shown to inhibit in vitro biofilm formation and proliferation of one of the main bacterial pathogens in dental caries, especially in early-childhood caries, namely Streptococcus mutans (Kang et al., 2005). This inhibition occurred via the water solublepolymers produced from sucrose by Weissella. Moreover, using an in vivo study on 72 volunteers who rinsed their teeth after brushing in the morning, afternoon and evening, with a rinse that contained the potential probiotic $W$. cibaria strain, a significant
$20 \%$ reduction in plaque scores could be achieved. This indicated a high potential of $W$. cibaria isolates to inhibit biofilm formation (Kang et al., 2005). Hydrogen peroxide-producing weissellas, belonging to the $W$. cibaria species, were also isolated from children's saliva and were capable of inhibiting the in vitro production of halitosis indicators such as volatile sulfur compounds (VSC) produced by Fusobacterium nucleatum. Furthermore, these bacteria could inhibit the proliferation of five periodontopathic bacteria, including F. nucleatum. Moreover, clinical studies based on gargling with the best performing $W$. cibaria isolate resulted in a significant in vivo reduction of the level of VSC (Kang et al., 2006a,b). An in vitro antiflammatory activity of $W$. cibaria, which consisted of inhibition of interleukin (IL)-6 and IL-8 production from human mouth epithelial cells that were originally elicited by F. nucleatum, could also be demonstrated in vitro, highlighting once again the high probiotic potential of W. cibaria in controlling periodontal disease (Kang et al., 2011). For all these reasons, Kang et al. (2012) successfully investigated the stability of probiotic chewing gum containing a $W$. cibaria strain.

Moon et al. (2012) demonstrated in an in vitro study that intracellular lipid accumulation in 3T3-L1 cells could be inhibited by the ornithine rich cytoplasmic extract of $W$. koreensis OK16. Lately, it was demonstrated that kimchi fermented with this $W$. koreensis strain as starter culture has an anti-obesity effect in high-fat diet-induced obese mice (Park et al., 2012).

Nevertheless, it should be considered that the current legislation on probiotics and probiotic foods/feed is very different worldwide, with a stricter regulatory framework in the European Community. Indeed, the Panel on Dietetic Products, Nutrition and Allergies of the European Food Safety Authority has rejected more than 300 health claims on the benefits of probiotic bacteria, resulting in not one of the probiotic products being allowed to claim a health benefit for the strains they contain. As a consequence, in Europe not a single probiotic product, food or supplement, can mention the health benefits of the strains it includes. Moreover, considering that the most current and accepted definition (the FAO/WHO panel definition) of probiotics define them as "live microorganisms which when administered in adequate amounts confer a health benefit on the host" (Hill et al., 2014), even the word "probiotic" would not be allowed in the definition. These findings, together with the role as opportunistic pathogens of some weissellas and the intrinsic resistance to vancomycin and other antibiotics (Ouoba et al., 2008; Ayeni et al., 2011; Muñoz-Atienza et al., 2013), may drastically reduce the potential use of these bacteria as probiotics or even only as pro-technological (starter) bacteria in food, feed and supplements. Therefore, before thinking about using a Weissella strain for biotechnological and probiotic purposes, a thorough, strain-specific safety assessment would be mandatory.

\section{EPS and Prebiotics Producing Strains}

The ability to produce dextran is one of the distinctive phenotypic features of the genus Weissella (Collins et al., 1993; Björkroth and Holzapfel, 2006). In particular, strains of $W$. confusa and $W$. cibaria have received high attention in the last decade due to their ability to produce significant amounts of dextran (De 
TABLE 6 | Weissella species from human and animal clinical specimens.

\begin{tabular}{|c|c|c|}
\hline Species & Source & References \\
\hline \multirow[t]{2}{*}{ W. ceti } & $\begin{array}{l}\text { Diseased beaked whales (Mesoplodon bidens) (muscle tissue, brain, kidney, lymph nodes, spleen of four different } \\
\text { animals). }\end{array}$ & Vela et al., 2011 \\
\hline & diseased rainbow trout (Oncorhynchus mykiss) & $\begin{array}{l}\text { Liu et al., 2009; Figueiredo } \\
\text { et al., } 2012\end{array}$ \\
\hline \multirow[t]{4}{*}{ W. cibaria } & Dog ear (otitis) & Björkroth et al., 2002 \\
\hline & Human blood (bacteremia) & Kulwichit et al., 2007 \\
\hline & Human lung swab (bacteremia) & Kulwichit et al., 2007 \\
\hline & Human urine & Kulwichit et al., 2007 \\
\hline \multirow[t]{18}{*}{ W. confusa } & Blood of a neonatal foal with septicemia & Lawhon et al., 2014 \\
\hline & Intestine, lung, liver, and brain of a female mona monkey (Cercopithecus mona) with systemic infection & Vela et al., 2003 \\
\hline & Human feces, Human gall, Human drain, necropsy specimens of a dog & Björkroth et al., 2002 \\
\hline & Human blood cultures (of patients with bacteremia) & Olano et al., 2001 \\
\hline & Human feces (children) & Green et al., 1990 \\
\hline & Human feces (of pediatric liver transplant recipients) & Green et al., 1991 \\
\hline & Human peritoneal fluids (after hemicolectomy) and abdominal walls of two patients & Riebel and Washington, 1990 \\
\hline & Human blood (of patients with monomicrobial bacteremia) & Kumar et al., 2011 \\
\hline & Human blood (in an immune competent patient with underlying intramural hematomas of the aorta) & Lee et al., 2013 \\
\hline & Human blood of 10 patients with bacteremia & Lee et al., 2011 \\
\hline & Human blood cultures (of patients with infective endocarditis) & $\begin{array}{l}\text { Flaherty et al., 2003, Shin } \\
\text { et al., } 2007\end{array}$ \\
\hline & Purulent material from the thumb abscess of human & Bantar et al., 1991 \\
\hline & Human blood (bacteremia) & Harlan et al., 2011 \\
\hline & Human blood (bacteremia) & Kulwichit et al., 2007 \\
\hline & Human bone (osteomyelitis) & Kulwichit et al., 2007 \\
\hline & Human blood from patient with bacteremia & Salimnia et al., 2011 \\
\hline & Human blood of two patients with bacteremia & Fairfax et al., 2014 \\
\hline & Human aspirate from a knee with prosthetic joint & Medford et al., 2014 \\
\hline \multirow[t]{2}{*}{ W. viridescens } & Fecal DNA from celiac children & Sanz et al., 2007 \\
\hline & Human blood (bacteremia) & Kulwichit et al., 2007 \\
\hline Weissella spp. & Human feces of children diagnosed with human immunodeficiency virus (HIV) & Dicks et al., 2009 \\
\hline
\end{tabular}

Bruyne et al., 2008, 2010; Maina et al., 2008, 2011, 2013, 2014; Björkroth et al., 2009; Katina et al., 2009; Bounaix et al., 2010; Padonou et al., 2010; Ahmed et al., 2012; Amari et al., 2013; Bejar et al., 2013; Rao and Goyal, 2013a,b; Shukla et al., 2014; Wolter et al., 2014; Tingirikari et al., 2014a,b; Malang et al., 2015), fructan and heteropolysaccharides (Tieking et al., 2003; Di Cagno et al., 2006; Malik et al., 2009; Malik, 2012; Malang et al., 2015), and novel non-digestible oligosaccharides (Chun et al., 2007; Kang et al., 2009; Patel et al., 2013; Immerzeel et al., 2014). These latter are raising interest due to their prebiotic potential, as they may (i) decrease the risk of infections and diarrhea, (ii) increase bowel function and metabolism, and (iii) pass through the gastrointestinal tract and stimulate the growth of resilient beneficial bacteria, mainly the bifidobacteria (Rastall and Gibson, 2014). Apart from their postulated health benefit, prebiotic oligosaccharides may be used in a wide range of applications in clinical, cosmetics, food and feed industries as sweeteners, humectants, possible weight controlling agents and dietary fibers (Patel and Goyal, 2011).
The dextrans produced by Weissella spp. have similar structures with mainly (ca. 97\%) $\alpha-(1-6)$ linkages and only ca. $3 \%$ $\alpha-(1-3)$ linkages (Katina et al., 2009; Bounaix et al., 2010; Maina et al., 2011, 2013; Ahmed et al., 2012; Bejar et al., 2013). This makes dextran-producing strains of $W$. cibaria and $W$. confusa very appealing for a wide range of industrial applications, especially for bakery applications (Di Cagno et al., 2006; Schwab et al., 2008; Katina et al., 2009; Coda et al., 2010, 2014; Galle et al., 2010, 2012; Ruehmkorf et al., 2012; Wolter et al., 2014; Kajala et al., 2015) and for the production of cereal-based, LAB fermented functional beverages (Zannini et al., 2013).

\section{Isolation, Identification, Typing, and Detection}

Pepe et al. (2001) differentially isolated and enumerated W. paramesenteroides on Modified Chalmers Agar on which convex colonies of $2 \mathrm{~mm}$ with pale-pink colonies containing a small 
TABLE 7 | Bacteriocinogenic Weissella strains, class, name, organisms against which the bacteriocins were active and relevant reference.

\begin{tabular}{|c|c|c|c|c|}
\hline Name & Class & Producer organisms & Sensitive indicator strains & References \\
\hline $\begin{array}{l}\text { Weissellicin } \\
110\end{array}$ & Unclassified & W. cibaria 110 & $\begin{array}{l}\text { Lactobacillus sakei JCM 1157, L. sanfranciscensis JCM 5668, L. homohiochii } \\
\text { JCM 1199, L. coryniformis subsp. coryniformis, JCM 1164, L. acetotolerans } \\
\text { JCM 3825-Weissella halotolerans JCM1114, W. kandleri JCM 5817, W. } \\
\text { paramesenteroides JCM 9890, Leuconostoc lactis JCM } 6123\end{array}$ & Srionnual et al., 2007 \\
\hline Weissellin A & Class IIA & $\begin{array}{l}\text { W. paramesenteroides } \\
\text { DX }\end{array}$ & $\begin{array}{l}\text { Bacillus cereus LMG13569, Clostridium sporogenes NCTC533, } \\
\text { C. thiaminolyticum ATCC15579, Enterococcus faecalis NCTC8176, } \\
\text { Lactobacillus brevis ATCC8287, L. bulgaricus LMG13551, L. casei ATCC344, } \\
\text { L. curvatus ATCC51436, L. jensenii ATCC25258, L. plantarum CECT220, L. } \\
\text { sakei CECT906T, Lactococcus lactis LM0230, Lact. lactis ATCC11454, Lact. } \\
\text { lactis IL1403, Lact. lactis subsp. cremoris MC1363, Leuconostoc } \\
\text { mesenteroides ATCC19254, Listeria innocua ATCC BAA-680D, List. } \\
\text { monocytogenes ATCC19111, Micrococcus luteus CECT241, Pediococcus } \\
\text { acidilactici ATCC25740, P. pentosaceus ATCC } 33316, \text { P. pentosaceus } \\
\text { LMG13560, Staphylococcus carnosus LMG13564 }\end{array}$ & $\begin{array}{l}\text { Papagianni and } \\
\text { Papamichael, } 2011\end{array}$ \\
\hline Weissellicin L & Unclassified & W. hellenica 4-7 & $\begin{array}{l}\text { L. monocytogenes ATCC 19111, L. sakei subsp. sakei JCM 1157, } \\
\text { L. bulgaricus ATCC 11842, W. paramesenteroides ATCC33313, W: hellenica } \\
\text { ATCC 51523, W. viridescens ATCC 12706, S. thermophilus ATCC } 19258\end{array}$ & Leong et al., 2013 \\
\hline Weissellicin D & Unclassified & W. hellenica D1501 & $\begin{array}{l}\text { L. lactis ssp. lactis, Lactobacillus fermentum ATCC 14931, Lb. sake, Lb. } \\
\text { plantarum 70810, Lb. bulgaricus ATCC 7830, Lb. helveticus Mb2-1, Lb. } \\
\text { paracasei, Lb. curvatus, Lb. brevis, Pediococcus pentosaceus } \\
\text { CGMCC1.2695, Streptococcus thermophilus CGMCC1.6472, } \\
\text { Staphylococcus aureus ATCC 6538, Bacillus subtilis ATCC 6633, B. cereus } \\
\text { ATCC 11778, Pseudomonas aeruginosa, Listeria monocytogenes CMCC } \\
\text { 54004, Micrococcus luteus CMCC28001, Saccharomyces cerevisiae ATCC } \\
\text { 26603, Debaromyces hansenii ATCC 4143, Kluyveromyces marxianus, } \\
\text { Candida albicans CMCC 28001, Mucor CICC } 2521\end{array}$ & Chen et al., 2014a \\
\hline $\begin{array}{l}\text { Weissellicin M } \\
\text { Weissellicin } Y\end{array}$ & $\begin{array}{l}\text { Unclassified } \\
\text { Unclassified }\end{array}$ & W. hellenica QU 13 & $\begin{array}{l}\text { a L. lactis ssp. lactis ATCC 19435T, L. lactis ssp. lactis NCDO 497, } \\
\text { Lactobacillus sakei ssp. sakei JCM 1157T, Lb. plantarum JCM 1149T, } \\
\text { Weissella cibaria JCM 12495T, W. hellenica JCM 10103T, } \\
\text { W. paramesenteroides JCM 9890T, W. confusa JCM 1093T, Pediococcus } \\
\text { pentosaceus JCM 5885, P. dextrinicus JCM 5887T, P. acidilactici JCM 8797T, } \\
\text { Enterococcus faecium JCM 5804T, E. durans NBRC 100479T, E. faecalis JCM } \\
\text { 5803T, Streptococcus bovis JCM 5802T, Str. dysgalactiae ssp. dysgalactiae } \\
\text { JCM 5673, Bacillus coagulans JCM 2257T, B. circulans JCM 2504T, B. } \\
\text { subtilis ssp. subtilis JCM 1465T, B. cereus JCM 2152T, Kocuria rhizophila } \\
\text { NBRC 12708, Listeria innocua ATCC 33090T, Leuconostoc mesenteroides } \\
\text { ssp. mesenteroides JCM 6124T }\end{array}$ & Masuda et al., 2012 \\
\hline
\end{tabular}

${ }^{a}$ Both bacteriocins were active against these bacteria but weissellicin Y showed an overall weaker activity than weissellicin M.

fuchsia center are formed. Zamudio-Maya et al. (2008) used an enrichment in MRS broth followed by plating on MRS agar added with 2,3,5-triphenyltetrazolium chloride (TTC), which allowed the differential isolation of LAB including several $W$. confusa and $W$. cibaria strains from sediments of a coastal marsh. However, apart from these two descriptions, there are no differential selective media available so far for isolation and enumeration of weissellas. Media for presumptive lactobacilli and leuconostocs such as MRS (De Man et al., 1960), which is generally used to cultivate weissellas, LUSM (Benkerroum et al., 1993) and SDB (Kline and Sugihara, 1971) have also been used. Due to the use of vancomycin in the LUSM medium, it may be considered the most selective and useful medium among those mentioned above, although it does not differentiate vancomycin-resistant Leuconostoc from weissellas. As for other lactic acid bacteria, the biochemical identification of Weissella species, apart from being time-consuming and labor intensive, may be uncertain or lead to misidentification, especially for species with very similar phenotypes. Weissella species have previously been distinguished by comparison of cellular fatty acids profiles (Samelis et al., 1998), by total soluble cell protein patterns (Dicks, 1995; Tsakalidou et al., 1997), and furthermore by biochemical-based commercial identification kits such as the RapID ${ }^{\mathrm{TM}}$ STR System (Thermo Scientific, Hudson, NH, USA), the API 50 CHL kit (BioMérieux, Lyon, France) (Lee et al., 2012), the Phoenix Automated Microbiology System (Becton DickinsonDiagnostic Systems, Sparks, MD) and the Vitek 2 system (BioMerieux, Marcy l'Etoile, France). But even these advanced tools may fail in discriminating closely related species, due to the variability and instability of phenotypic characters and the subjectivity in the interpretation of results (Graef et al., 2005; Koort et al., 2006; Shin et al., 2007; Kulwichit et al., 2008; Fusco et al., 2011; Lee et al., 2011; Fairfax et al., 2014; 
Medford et al., 2014). Such is the case, for example, with the two closely related species $W$. cibaria and $W$. confusa, which differ in the capability of the latter to ferment galactose and xylose, while $W$. cibaria produces acid only from L-arabinose (Björkroth et al., 2002; Fusco et al., 2011). To overcome these drawbacks, molecular methods such as 16S rRNA gene sequencing (Kulwichit et al., 2008; Fairfax et al., 2014; Medford et al., 2014), amplified ribosomal DNA restriction analysis (ARDRA) (Jang et al., 2002) and ribotyping (Björkroth et al., 2002) have been used to identify and detect Weissella species. Schillinger et al. (2008) designed a Weissella and Leuconostoc genus specific primer set targeting in the 16S rRNA gene, while Fairfax et al. (2014) used Matrix-assisted laser desorption ionization Time-of-Flight (Maldi-ToF) to identify two W. confusa clinical isolates. Walter et al. (2001) designed a primer set allowing the PCR amplification of $16 \mathrm{~S}$ rRNA gene fragments of the genera Lactobacillus, Pediococcus, Leuconostoc, and Weissella, whose separation by denaturing gradient gel electrophoresis resulted in the detection of numerous species belonging to these genera. However, it should be mentioned that, using a gel with a $32.5-40 \%$ gradient of urea and formamide increasing in the direction of electrophoresis, a co-migration of the band relevant to $W$. confusa and $L b$. reuteri was obtained (Walter et al., 2001).

A species-specific PCR, which has been used for the identification and detection of $W$. confusa from foods and clinical specimens, has also been designed (Fusco et al., 2011). Moreover, Snyder et al. (2014) developed a conventional PCR and a quantitative PCR for identification and quantification of $W$. ceti NC36 from pure cultures and tissue samples.

The molecular typing of weissellas was achieved by numerical analysis of HindIII and EcoRI ribopatterns (Koort et al., 2006), repetitive element-PCR fingerprinting using (GTG) $)_{5}$ PCR (Bounaix et al., 2010) and fluorescent-Amplified Fragment Length Polymorphism (fAFLP) (Fusco et al., 2011). Chelo et al. (2010) analyzed genome diversity in the genera Fructobacillus, Leuconostoc, and Weissella by constructing physical and genetic maps, based on pulsed field gel electrophoresis (PFGE) analysis of macro-restriction fragments and hybridization of genetic markers of several strains belonging to these genera. This provided further insights into the evolution and diversification of the species of the genera Leuconostoc, Oenococcus, and Weissella.

\section{Description of Species of the Genus Weissella}

Currently, the genus Weissella consists of 19 species (see below). A detailed description of the currently valid described Weissella species is given below:

\section{Weissella beninensis (Padonou et al., 2010)}

ben.in.en'sis.N.L.fem.adj. beninensis, pertaining to Benin.

Weissella beninensis is currently the only known motile species of Weissella. Motility was observed by phase contrast microscopy and peritrichous flagella could be visualized by scanning electron microscopy (Padonou et al., 2010). Clustering analysis based on 16S rRNA gene sequences showed $W$. beninensis to cluster with
W. ghanensis as its nearest neighbor (Padonou et al., 2010), while DNA:DNA hybridization experiments showed that $W$. beninensis was a distinct species, when compared to the nearest neighbor $W$. ghanensis. Cells grow at $15^{\circ} \mathrm{C}$ but not at $45^{\circ} \mathrm{C}$, at a $\mathrm{pH}$ range between 3.9 and 8.0 and in medium with $4 \% \mathrm{NaCl}$. Ammonia is produced from arginine and gas from glucose catabolism. Both the $\mathrm{D}$ and the $\mathrm{L}$ lactic acid enantiomers are produced as end products of glucose fermentation. Acid is produced from galactose, lactose, melibiose, raffinose and sucrose, but not from arabinose and xylose. The mol\% G+C content is $37.0-37.2 \%$.

\section{Weissella ceti (Vela et al., 2011)}

ce.ti. L. gen. n. ceti, of a whale.

Bacteria are short rod-shaped or cocci and non-motile. They grow in the presence of $3.0-6.5 \% \mathrm{NaCl}$, at $\mathrm{pH} 3.9$ and $37^{\circ} \mathrm{C}$, but not at 15 or $42^{\circ} \mathrm{C}$ (Vela et al., 2011). Both the D and the $\mathrm{L}$ lactic acid enantiomers are formed at a ratio of 80:20, respectively. Gas is not produced from glucose metabolism (Vela et al., 2011) which is unusual for a species of this group of organisms as these are all obligately heterofermentative and thus generally should generate gas from glucose fermentation. A 16S rRNA gene sequence analysis showed that $W$. ceti grouped together with $W$. halotolerans, $W$. viridescens and $W$. minor in a well-defined cluster (Vela et al., 2011). Hydrolysis of arginine is variable and strain dependent. Acid is produced from ribose, trehalose and maltose, but not from xylose, galactose, fructose, cellobiose, lactose, sucrose and raffinose. Dextran is not formed from sucrose and both the $\mathrm{D}$ and $\mathrm{L}$ enantiomers of lactic acid are produced. The mol\% $\mathrm{G}+\mathrm{C}$ content of the DNA is $39.2 \%$. DNA:DNA hybridization was not done to confirm the novel species status of W. ceti, despite a high (99.5\%) similarity of the 16S rRNA gene sequence to that of other Weissella gene sequences in the database (not specified in the publication by Vela et al., 2011).

\section{Weissella cibaria Björkroth et al. (2002, p. 147 ${ }^{\mathrm{VP}}$ )}

ci.ba'ri.a.L.adj.cibaria, pertaining to food.

Weissella cibaria strains originating from Thai fermented foods or from clinical samples were described by Björkroth et al. (2002). These authors noticed that a group of $W$. confusa strains possessed closely related protein fingerprinting patterns and ribotypes, but could nevertheless be distinguished into two distinct groups. These strains were investigated further using, amongst other techniques, 16S rRNA gene analyses and DNA:DNA hybridization and the novel species $W$. cibaria, which is closely related to $W$. confusa, could be distinguished. $W$. cibaria is able to grow at 15 and at $45^{\circ} \mathrm{C}$, but not at $4^{\circ} \mathrm{C}$ (Björkroth et al., 2002). The bacteria tolerate the presence of $6.5 \% \mathrm{NaCl}$. W. cibaria strains hydrolyse arginine and produce both the $\mathrm{D}$ and $\mathrm{L}$ lactic acid enantiomer as end product of glucose fermentation. $\mathrm{CO}_{2}$ is also generated from glucose metabolism. Acid is produced from arabinose, cellobiose, salicin, sucrose and xylose, but not from galactose, lactose, melibiose, raffinose, ribose and trehalose. Dextran is formed from sucrose. The mol\% $\mathrm{G}+\mathrm{C}$ content of the DNA is $44-45 \%$ (Björkroth et al., 2002). 
In 2002, Choi et al. described a novel species W. kimchii isolated from a traditional vegetable fermentation in Korea. This species was described on the basis of DNA:DNA hybridization, $16 \mathrm{~S}$ rRNA gene phylogenetic analyses, as well as phenotypic and biochemical testing. The strain was shown to be very similar to $W$. confusa, but differing from this species on the basis of phenotypic characteristics, whole cell protein patterns and DNA:DNA hybridization data (Choi et al., 2002). The species W. kimchii was, however, re-classified as W. cibaria by Ennahar and Cai (2004), as W. kimchii was shown to be a later heterotypic synonym of W. cibaria based on 16S rRNA gene sequencing and DNA:DNA hybridization tests. The publication of Choi et al. (2002) in which W. kimchii was first described did not compare this species to W. cibaria (Björkroth et al., 2002), probably because the authors did not yet have knowledge of the $W$. cibaria species. The latter was also published in 2002, albeit at an earlier time. Therefore, given the earlier publication of the $W$. cibaria description in a work on similar bacteria, Ennahar and Cai (2004) proposed $W$. kimchii to be a later heterotypic synonym of $W$. cibaria.

Weissella confusa Collins et al. (1993, p. 599 $\left.{ }^{\mathrm{AL}}\right)$ Synonyms: Lactobacillus confusus Sharpe et al. (1972, p. 396); Lactobacillus coprophilus subsp. confusus Holzapfel and Kandler (1969, 665).

con.fu'sus.L.v. confundere; L. past part. confusus confused.

These bacteria are heterofermentative and produce both the $\mathrm{D}$ and $\mathrm{L}$ lactic acid enantiomers when fermenting glucose. Cells are short rods which tend to thicken at one end. The ability to grow at $45^{\circ} \mathrm{C}$ is strain dependent, with some strains showing good growth at this temperature. Ammonia results from arginine breakdown and acid is produced from cellobiose, galactose, ribose, salicin, sucrose and xylose, but not from arabinose, lactose, melibiose, raffinose and trehalose fermentation. Dextran is formed from sucrose. The mol\% G+C content of the DNA is $45-47 \%$ (Collins et al., 1993).

\section{Weissella diestrammenae (Oh et al., 2013)}

di.es.tram.me'nae. N.L. gen. n. diestrammenae of Diestrammena, referring to Diestrammenacoreana, a camel cricket from the gut from which the bacteria were isolated.

Cells are coccoid- or rod-shaped and growth occurs from 4 to $37^{\circ} \mathrm{C}$, in $0-4 \%(\mathrm{w} / \mathrm{v}) \mathrm{NaCl}$ and at $\mathrm{pH} 5-8$ (Oh et al., 2013). Bacteria are heterofermentative and produce gas from glucose, they are able to hydrolyse arginine and produce gas from glucose. The cell wall contains Lys-Ala-Ser and cells produce the D-enantiomer of lactic acid. The mol\% G+C content of the DNA is $45 \%$ and acid is produced from mannose, acetylglucosamine, xylose and maltose but not from fructose, mannitol, and galactose. Cells are able to hydrolyse esculin and to produce ammonia from arginine (Oh et al., 2013).

Weissella fabalis (Snauwaert et al., 2013)

fa.ba’lis. L. fem. adj. fabalis of or belonging to beans.
Bacteria were isolated from fermenting cocoa and 16S rRNA gene sequence analysis showed that this bacterium was most closely related to $W$. fabaria and occurred together with this species, $W$. beninensis and $W$. ghanensis in a well-separated cluster (Snauwaert et al., 2013). Cells are non-motile cocci, which produce gas from glucose in a heterofermentative metabolism. This bacteria produces the $\mathrm{D}$ lactic acid enantiomer, grows at $15-37^{\circ} \mathrm{C}$ and in the presence of $5-6 \% \mathrm{NaCl}$, but not in the presence of 7-8\% $\mathrm{NaCl}$ (Snauwaert et al., 2013). Acid is formed from fructose, cellobiose, trehalose and gentiobiose, but not from arabinose, ribose, xylose, galactose, lactose, melibiose, sucrose and raffinose. Arginine is hydrolyzed. The mol\% G+C content is $37 \%$ (Snauwaert et al., 2013).

\section{Weissella fabaria (De Bruyne et al., 2010)}

fa.ba'ri.a. L. fem. adj. fabaria, of or belonging to beans.

Bacteria were also isolated from fermenting cocoa and are heterofermentative producing $\mathrm{CO}_{2}$ from glucose metabolism. They furthermore produce both the $\mathrm{D}$ and L lactate enantiomer in an approximate 90:10 ratio, respectively (De Bruyne et al., 2010). Cells are non-motile, coccoid with growth occurring at $15-37^{\circ} \mathrm{C}$ and at $\mathrm{pH}$ 5.0-9.0. No growth occurred in the presence of 5\% $\mathrm{NaCl}$. W. fabaria hydrolyses arginine and acid is produced from fructose, mannose, cellobiose, trehalose and gentiobiose, but not from arabinose, ribose, raffinose, sucrose, xylose, galactose, lactose, and melibiose. According to a 16S rRNA gene sequence analysis, $W$. fabaria was shown to be closely related to $W$. ghanensis and occurred together with this species, as well as with $W$. fabalis and $W$. beninensis in a well-delineated cluster (De Bruyne et al., 2010; Snauwaert et al., 2013; Björkroth et al., 2014). The mol\% G+C content of the DNA is $38.2 \%$ (De Bruyne et al., 2010).

\section{Weissella ghanensis (De Bruyne et al., 2008)}

gha.nen'sis.N.L.fem.adj. ghanensis, pertaining to Ghana.

Weissella ghanensis was also isolated from fermenting cocoa. These bacteria are small rods, appearing singly or in chains and are non-motile. $W$. ghanensis grows at $15-37^{\circ} \mathrm{C}$, but similar to W. fabaria, it does not grow in the presence of $5 \% \mathrm{NaCl}(\mathrm{De}$ Bruyne et al., 2008). The strain produces gas $\left(\mathrm{CO}_{2}\right)$ from glucose fermentation, with both the $\mathrm{D}$ and $\mathrm{L}$ lactic acid enantiomers being produced at a ratio of approx. 90:10 or 95:5, respectively, depending on the strain (De Bruyne et al., 2008).W. ghanensis hydrolyses esculin and produces ammonia from arginine. Acid is produced from cellobiose, fructose, maltose, salicin and trehalose, with no acid being produced from arabinose, galactose, melibiose, raffinose, ribose and xylose. The mol\% G+C content of the DNA is $40 \%$.

\section{Weissella halotolerans Collins et al. (1993, p. $599^{\mathrm{VP}}$ )}

Synonym: Lactobacillus halotolerans Kandler et al. (1983). (p. 672). Effective publication: Kandler et al. (1983); Kandler et al. (p. 283). 
ha.lo.to'le.rans. Gr. N. hals, halos, salt; L. part. adj. tolerans, tolerating, enduring: N.L. part. adj. halotolerans, salt tolerating.

Weissella halotolerans was originally described as "Lactobacillus viridescens subsp. halotolerans" by Reuter (1970), but this name was not on the Approved List of Bacterial Names of Skerman et al. (1989). "Lactobacillus halotolerans" was subsequently described by Kandler et al. (1983) as irregular short, even coccoid rods with rounded ends and with a tendency to form coiling chains and lumping together. Growth of these bacteria occurred between 10 and $40^{\circ} \mathrm{C}$, with good growth occurred only from $12^{\circ} \mathrm{C}$. Very weak growth could be demonstrated at $14 \% \mathrm{NaCl}$. "L. halotolerans" was shown to ferment fructose, glucose, gluconate, maltose, mannose, ribose and trehalose, but not cellobiose, galactose, lactose, mannitol, melizitose, melibiose, raffinose, rhamnose, sorbitol, sucrose, xylose and esculin. The cell wall murein type was Lys-Ala-Ser and the mol\% G+C content of the DNA was 45\% (Kandler et al., 1983). Some 10 years later, Collins et al. (1993) finally reclassified "Lactobacillus halotolerans" as Weissella halotolerans.

\section{Weissella hellenica Collins et al. (1993, p. $601^{\mathrm{VP}}$ )}

hel.en'i.ca.Gr.adj.Hellenikos, Greek; N.L. fem. adj. hellenica, Greece, from where this bacterium was first isolated.

Bacteria are non-motile and of spherical, but sometimes lenticular shape, usually occurring in pairs or short chains, with a tendency to form clusters (Collins et al., 1993). Cells grow at $10^{\circ} \mathrm{C}$, show delayed growth at $4^{\circ} \mathrm{C}$ and do not grow at $37^{\circ} \mathrm{C}$. The bacteria are heterofermentative but gas production is poor. The cells produce predominantly ( $>98 \%$ ) D-lactate, they do not hydrolyse arginine. Growth occurs at $8 \%$ but not at $10 \% \mathrm{NaCl}$, or in medium at $\mathrm{pH} 4.8-5.0$. They are Vogues-Proskauer negative. Acid is produced from glucose, fructose, mannose, maltose, trehalose but not from ribose, xylose, rhamnose, mannitol, cellobiose, lactose, melizitose and raffinose. The cell wall peptidoglycan belongs to the Lys-Ala-Ser(Ala)- type and the G+C content of the DNA was reported to range from 39.4 to $40 \mathrm{~mol} \%$ (Collins et al., 1993).

\section{Weissella kandleri Collins et al. (1993, p. 599 ${ }^{\mathrm{VP}}$ )}

Synonym: Lactobacillus kandleri Holzapfel and van Wyk (1983) (p. 439). Effective publication: Holzapfel and van Wyk (1982); Holzapfel and van Wyk (p. 501).

kand'le.ri. M.L. gen. n. kandleri, of Kandler; named after O. Kandler, a German microbiologist.

Cells are of irregular rod shape occurring singly or in pairs. The interpeptide bridge is Lys-Ala-Gly-Ala 2 . Both the D- and the L-enantiomers of lactate are produced. Dextran is generated from sucrose, ammonia is produced from arginine. No growth occurs at $45^{\circ} \mathrm{C}$. The $\mathrm{G}+\mathrm{C}$ content of the DNA is $39 \mathrm{~mol} \%$. Acid is produced from galactose, ribose but not from arabinose, cellobiose, maltose, melibiose, raffinose, sucrose, trehalose and xylose (Holzapfel and van Wyk, 1983).
Weissella koreensis Lee et al. (2002). (p. 1260 ${ }^{\mathrm{VP}}$ )

ko.re.en'sis.N.L.koreensis of Korea.

W. koreensis was isolated from Korean kimchi and is most closely related to $W$. kandleri on basis of a $16 \mathrm{~S}$ rRNA gene nucleotide analysis. $W$. koreensis bacteria are not motile and the cells are irregular, short and rod-shaped or coccoid. These bacteria were able to grow at 10 and $37^{\circ} \mathrm{C}$ but not at $42^{\circ} \mathrm{C}$. Cells also grew in a $\mathrm{pH}$ range of $\mathrm{pH} 4.0-8.0$, but not in the presence of 8 or $10 \% \mathrm{NaCl}$. Arginin was hydrolysed and acid was produced from arabinose, ribose and xylose, but not from cellobiose, galactose, maltose, melibiose, raffinose, sucrose or trehalose. The bacteria form exclusively the D lactic acid enantiomer. The cell wall was shown to contain Lys-Ala-Ser and the mol\% G+C content of the DNA was 37 mol\% (Lee et al., 2002).

\section{Weissella minor Collins et al. (1993, p. 599 ${ }^{\mathrm{VP}}$ )}

Synonyms: Lactobacillus minor Kandler et al. (1983). (p. 672). Effective publication: Kandler et al. (1983). (p. 284) (Lactobacillus corynoides subsp. minor Abo-Elnaga and Kandler (1965) (p. 128); Lactobacillus viridescens subsp. minor Kandler and Abo-Elnaga (1966) (p. 754).

mi'nor. L. comp. adj. minor smaller.

W. minor was previously classified as a subspecies of Lactobacillus viridescens, i.e., L. viridescens subsp. minor (Abo-Elnaga and Kandler, 1965), similar to the case of W. halotolerans which was previously classified as Lactobacillus viridescens subsp. halotolerans (Reuter, 1970; Kandler et al., 1983). These bacteria were re-classified to "Lactobacillus minor" by Kandler et al. (1983) who described these bacteria as occurring as irregular, short rods with rounded to tapered ends, often bent and with unilateral swelling. Bacteria were non-motile and were able to grow between 10 and $40^{\circ} \mathrm{C}$. Good growth could be shown to occur up to $8 \% \mathrm{NaCl}$, and very weak growth at $10 \% \mathrm{NaCl}$. Nitrate was not reduced to nitrite, the cell wall contained murein of the Lys-Ser-Ala 2 type and the mol\% G+C content of the DNA was $44 \mathrm{~mol} \%$. The bacteria were able to produce acid from cellobiose, fructose, glucose, maltose, mannose, melizitose, ribose, sucrose, trehalose and esculin, but not from arabinose, galactose, lactose, mannitol, melibiose, raffinose, rhamnose, sorbitol, and xylose (Kandler et al., 1983).

\section{Weissella oryzae (Tohno et al., 2013)}

o.ry'za.e.L.gen.n. oryzae of rice, from which the type strain was isolated.

These bacteria from fermented rice grains were irregular, short rod-shaped or cocci and occurred singly or in pairs or short chains. Cells grew at $10-42^{\circ} \mathrm{C}$, but not at 4 or $50^{\circ} \mathrm{C}$. Growth also occurred at $\mathrm{pH} 3.9-9.0$ and with $4.0-6.5 \% \mathrm{NaCl}$, but not with $8 \%$ $\mathrm{NaCl}$ (Tohno et al., 2013). The cell wall peptidoglycan contains glutamic acid, lysine, serine and alanine and acid was produced from arabinose, ribose, xylose, galactose (delayed reaction), glucose, fructose, mannose, maltose, melibiose, trehalose and gluconate. Acid was not generated from arabinose, xylose, sorbose, rhamnose, dulcitol, inositol, mannitol, esculin, cellobiose, lactose, 
sucrose, melizitose, and raffinose. Esculin was not hydrolyzed, arginine hydrolysis was positive. Only the D lactic acid enantiomer was formed from carbohydrate fermentation. The mol\% $\mathrm{G}+\mathrm{C}$ content of the DNA was $40.6 \mathrm{~mol} \%$.

\section{Weissella paramesenteroides (Garvie, 1967; Collins et al., 1993) comb. nov.}

Gr. prep.para, beside; N.L. fem. adj. mesenteroides, a specific epithet; N.L. fem. adj. paramesenteroides, beside Leuconostoc mesenteroides.

Weissella paramesenteroides was proposed as a new species of the genus Leuconostoc by Garvie in 1967 based on differences to the closely related Leuconostoc mesenteroides regarding amino acid and vitamin requirements, and the failure to hydrolyze esculin and salicin. Morphologically, these bacteria are very similar to L. mesenteroides and do not form dextran from sucrose (Garvie, 1967) or ammonia from arginine. They are more tolerant toward $\mathrm{NaCl}$ than L. mesenteroides and can grow in media with an initial $\mathrm{pH}$ below 5 . The optimum growth temperature is $18-24^{\circ} \mathrm{C}$, but many strains also grow at $30^{\circ} \mathrm{C}$. The bacteria produce acid from galactose, maltose, melibiose, sucrose and trehalose. The peptidoglycan type is Lys-Ala 2 or Lys-Ser-Ala and the $\mathrm{G}+\mathrm{C}$ content of the DNA is $37-38 \mathrm{~mol} \%$. Based on $16 \mathrm{~S}$ rRNA gene sequencing analysis, the leuconostocs were shown to comprise three distinct lineages of which the "L. paramesenteroides" group (including the species formerly known as "L. confusus," "L. minor," "L. kandleri," "L. halotolerans," and "L. viridescens") were re-assigned to the genus Weissella by Collins et al. (1993). The re-classification of this new group included the new species W. paramesenteroides (Collins et al., 1993).

\section{Weissella soli (Magnusson et al., 2002)}

so'li.L.n. solum soil; L.gen.n.soli of the soil.

$W$. soli was isolated from garden soil in Uppsala, Sweden. Bacteria are non-motile rods that are thickened at one end and occurred singly or in pairs. The lactic acid enantiomer produced was mainly D-lacticacid. Growth occurred between 4 and $40^{\circ} \mathrm{C}$, but not at $42^{\circ} \mathrm{C}$. Acid was produced from ribose, D-xylose, glucose, mannose, maltose, melibiose, sucrose, trehalose and raffinose, but not from L-xylose, galactose, fructose, rhamnose, mannitol, cellobiose, lactose, and melizitose. Esculin was shown to be hydrolyzed and arginine was cleaved. The $\mathrm{G}+\mathrm{C}$ content of the DNA was $43 \%$ mol (Magnusson et al., 2002).

Weissella thailandensis (Tanasupawat et al., 2000) thai.lan'den.sis.M.L.fem. adj. thailandensis pertaining to Thailand, where the strains were first isolated.

W. thailandensis was isolated from fermented fish (pla-ra) in Thailand and cells were non-motile and coccus-shaped. These bacteria did not reduce nitrate and did not hydrolyze arginine, esculin, gelatin or starch. The bacteria were able to grow in $10 \%$ $\mathrm{NaCl}$, at temperatures of $25-37^{\circ} \mathrm{C}$ but not at $42^{\circ} \mathrm{C}$. Growth also occurred at $\mathrm{pH} 8.0$, while no growth could be observed at $\mathrm{pH} 4.5$ or $\mathrm{pH}$ 8.5. Acid was produced from ribose, arabinose, fructose, galactose, mannose, maltose, melibiose, raffinose, and rhamnose, but not from cellobiose, mannitol, melizitose, sorbitol or xylose. The cell wall contains Lys-Ala 2 and the mol\% G+C content in the DNA was found to range from 38 to 41.2 (Tanasupawat et al., 2000).

\section{Weissella uvarum Nisiotou et al., 2014}

u.va'rum.L.fem. gen. pl. n. uvarum of grapes, where the type strain was isolated.

This bacterium was isolated from grapes from Nemea in Grecce. The cells were non-motile short rods, or showed coccoid morphology. The cells were able to grow at 15 and $42^{\circ} \mathrm{C}$, but not at 4 or $45^{\circ} \mathrm{C}$. Cells were not capable of growth at $\mathrm{pH} 3.9$ or in the presence of $6.5 \% \mathrm{NaCl}$, but could grow at $\mathrm{pH} 8.0$ and in the presence of $4 \% \mathrm{NaCl}$. Ammonia was produced from arginine and acid was produced from ribose, glucose, fructose, mannose, trehalose, melizitose, but not from glycerol, arabinose, xylose, galactose, rhamnose, mannitol, sorbitol, esculin, cellobiose, maltose, lactose, melibiose, sucrose, and raffinose (Nisiotou et al., 2014). The $\mathrm{mol} \% \mathrm{G}+\mathrm{C}$ content of the DNA and amino acid composition of the cell wall were not yet determined.

\section{Weissella viridescens (Niven and Evans., 1957; Collins et al., 1993) comb. nov.}

vi.ri.des'cens. M. L. pres. part.viridescens, growing green, greening.

The bacteria previously known as Lactobacillus viridescens were re-classified as Weissella viridescens by Collins et al. (1993). Cells are small rods, which occur either singly or in pairs, and the ends of the rods appear slightly tapered. Nitrate is not reduced and sodium hippurate, esculin, arginine and starch are not hydrolyzed. Growth occurs in the presence of $6.5 \% \mathrm{NaCl}$ and at the low temperature of $5^{\circ} \mathrm{C}$, but not at $45^{\circ} \mathrm{C}$. These bacteria ferment glucose, mannose, fructose and maltose, but no acid is produced from xylose, arabinose, galactose, lactose, raffinose or sorbitol (Niven and Evans, 1957). The interpeptide bridge of the peptidoglycan is composed of Lys-Ala-Ser. The mol\% $\mathrm{G}+\mathrm{C}$ of the DNA is 41-44 (Kandler and Weiss, 1986). Some strains produce large amounts of dextran from sucrose fermentation, a trait that may be lost rapidly in stock cultures (Niven and Evans, 1957).

\section{Conclusions}

The genus Weissella is a well-delineated genus within the family Leuconostocaceae and contains 19 validly described species. Weissella species are generally difficult to distinguish from other heterofermentative cocci such as leuconostocs, or rod-shaped bacteria such as certain Lactobacillus strains on the basis of phenotypic or biochemical properties alone. An accurate species identification thus is generally only possible using molecular biological methods, such as sequencing of $16 \mathrm{~S}$ rRNA or other house-keeping genes, DNA:DNA hybridization and by typing methods such as rep-PCR or fAFLP. Weissella occur in a great variety of habitats, including the skin, milk and feces of animals, the saliva, breast milk, feces and vagina of humans, on plants and 
vegetables, as well as in a variety of fermented foods such as European sourdoughs and Asian and African traditional fermented foods. Strains of some Weissella species, e.g., of $W$. viridescens, $W$. cibaria, and $W$. confusa, are known as opportunistic human pathogens causing infections such as bacteremia and endocarditis. Weissella ceti has also recently been shown to be the causative agent of "weissellosis" in farmed rainbow trout (Oncorhynchus mykiss) causing septicemia with a high mortality rate. On the other hand, there is some interest for biotechnological application of these bacteria, as specific strains have been investigated for use as probiotics, also for combatting periodontal disease. As Weissella strains feature quite prominently in some African

\section{References}

Abid, A., Davies, S. J., Waines, P., Emery, M., Castex, M., Gioacchini, G., et al. (2013). Dietary synbiotic application modulates Atlantic salmon (Salmo salar) intestinal microbial communities and intestinal immunity. Fish Shellfish Immunol. 35, 1948-1956. doi: 10.1016/j.fsi.2013.09.039

Abo-Elnaga, I. G., and Kandler, O. (1965). Zur Taxonomie der Gattung Lactobacillus Beijerinck. II. Das Subgenus Betabacterium Orla-Jensen. Zbl. Bakt., II. Abt. 119, 117-129.

Ahmed, R. Z., Siddiqui, K., Arman, M., and Ahmed, N. (2012). Characterization of high molecular weight dextran produced by Weissella cibaria CMGDEX3. Carbohydr. Polym. 90, 441-446. doi: 10.1016/j.carbpol.2012.05.063

Albesharat, R., Ehrmann, M. A., Korakli, M., Yazaji, S., and Vogel, R. F. (2011). Phenotypic and genotypic analyses of lactic acid bacteria in local fermented food, breast milk and faeces of mothers and their babies. Syst. Appl. Microbiol. 34, 148-155. doi: 10.1016/j.syapm.2010.12.001

Alfonzo, A., Ventimiglia, G., Corona, O., Di Gerlando, R., Gaglio, R., Francesca, N., et al. (2013). Diversity and technological potential of lactic acid bacteria of wheat flours. Food Microbiol. 36, 343-354. doi: 10.1016/j.fm.2013.07.003

Amari, M., Arango, L. F., Gabriel, V., Robert, H., Morel, S., Moulis, C., et al. (2013). Characterization of a novel dextransucrase from Weissella confusa isolated from sourdough. Appl. Microbiol. Biotechnol. 97, 5413-5422. doi: 10.1007/s00253-012-4447-8

Ampe, F., ben Omar, N., Moizan, C., Wacher, C., and Guyot, J.-P. (1999). Polyphasic study of the spatial distribution of microorganisms in Mexican pozol, a fermented maize dough, demonstrates the need for cultivation-independent methods to investigate traditional fermentations. Appl. Environ. Microbiol. 65, 5464-5473.

Aquilanti, L., Silvestri, G., Zannini, E., Osimani, A., Santarelli, S., and Clementi, F. (2007). Phenotypic, genotipic and technological characterization of predominant lactic acid bacteria in Pecorino cheese from central Italy. J. Appl. Microbiol. 103, 948-960. doi: 10.1111/j.1365-2672.2007.03513.x

Ayeni, F. A., Sánchez, B., Adeniyi, B. A., de Los Reyes-Gavilán, C. G., Margolles, A., and Ruas-Madiedo, P. (2011). Evaluation of the functional potential of Weissella and Lactobacillus isolates obtained from Nigerian traditional fermented foods and cow's intestine. Int. J. Food Microbiol. 147, 97-104. doi: 10.1016/j.ijfoodmicro.2011.03.014

Bae, S., Fleet, G. H., and Heard, G. M. (2006). Lactic acid bacteria associated with wine grapes from several Australian vineyards. J. Appl. Microbiol. 100, 712-727. doi: 10.1111/j.1365-2672.2006.02890.x

Bantar, C. E., Relloso, S., Castell, F. R., Smayevsky, J., and Bianchini, H. M. (1991). Abscess caused by vancomycin-resistant Lactobacillus confusus. J. Clin. Microbiol. 29, 2063-2064.

Beasley, S. S., Manninen, T. J., and Saris, P. E. (2006). Lactic acid bacteria isolated from canine faeces. J. Appl. Microbiol. 101, 131-138. doi: 10.1111/j.13652672.2006.02884.x

Bejar, W., Gabriel, V., Amari, M., Morel, S., Mezghani, M., Maguin, E., et al. (2013). Characterization of glucansucrase and dextran from Weissella sp. TN610 with potential as safe food additives. Int. J. Biol. Macromol. 52, 125-132. doi: 10.1016/j.ijbiomac.2012.09.014 fermented foods, or in European sourdough fermentations, the exploitation of specific strains as starter cultures may be considered. One technological interesting feature is also the production of copious amounts of dextrans and novel extracellular polysaccharides with potential prebiotic activity. This may be important for use in bakery products, for development, e.g., of cereal-based, LAB fermented functional beverages, or potentially for improving the viscosity and mouth-feel of fermented foods such as, e.g., fermented milk products. However, food producers should always be cognizant of the potential of Weissella strains for human opportunistic infection, and safety testing of any strain before use in biotechnological application is mandatory.

Belda, E., Pedrola, L., Peretó, J., Martínez-Blanch, J. F., Montagud, A., Navarro, E., et al. (2011). Microbial diversity in the midguts of field and lab-reared populations of the European corn borer Ostrinia nubilalis. PLoS ONE 6:e21751. doi: 10.1371/journal.pone.0021751

Belhadj, H., Harzallah, D., Bouamra, D., Khennouf, S., Dahamna, S., and Ghadbane, M. (2014). Phenotypic and genotypic characterization of some lactic acid bacteria isolated from bee pollen: a preliminary study. Biosci. Microbiota Food Health 33, 11-23. doi: 10.12938/bmfh.33.11

Benkerroum, N., Misbah, M., Sandine, W. E., and Elaraki, A. T. (1993). Development and use of a selective medium for isolation of Leuconostoc spp. from vegetables and dairy products. Appl. Environ. Microbiol. 59, 607-609.

Björkroth, J. A., Dicks, L. M. T. D., and Endo, A. (2014)."The genus Weissella," in Lactic Acid Bacteria, Biodiversity and Taxonomy, eds W. H. Holzapfel and B. J. B. Wood (Chichester: Wiley Blackwell), 418-428.

Björkroth, J. A., Dicks, L. M. T. D., and Holzapfel, W. H. (2009). “Genus III. Weissella Collins, Samelis, Metaxopoulos and Wallbanks 1994, 370VP (Effective publication: Collins, Samelis, Metaxopoulos, and Wallbanks 1993, 597)," in Bergey's Manual of Systematic Bacteriology, 2nd Edn., Vol. 3. The Firmicutes, eds P. de Vos, G. M. Garrity, D. Jones, N. R. Krieg, W. Ludwig, F. A. Rainey, et al. (New York, NY: Springer), 643-654.

Björkroth, J., and Holzapfel, W. H. (2006). "Genera Leuconostoc, Oenococcus and Weissella," in The Prokaryotes, eds M. Dworkin, S. Falkow, E. Rosenberg, K. Schleifer, and E. Stackebrandt (New York, NY: Springer), 267-319.

Björkroth, K. J., Schillinger, U., Geisen, R., Weiss, N., Hoste, B., Holzapfel, W. H., et al. (2002). Taxonomic study of Weissella confusa and description of Weissella cibaria sp. nov., detected in food and clinical samples. Int. J. Syst. Evol. Microbiol. 52, 141-148.

Bounaix, M. S., Robert, H., Gabriel, V., Morel, S., Remaud-Siméon, M., Gabriel, B., et al. (2010). Characterization of dextran-producing Weissella strains isolated from sourdoughs and evidence of constitutive dextransucrase expression. FEMS Microbiol. Lett. 311, 18-26. doi: 10.1111/j.1574-6968.2010.02067.x

Cai, Y., Benno, Y., Nakase, T., and Oh, T. K. (1998). Specific probiotic characterization of Weissella hellenica DS-12 isolated from flounder intestine. J. Gen. Appl. Microbiol. 44, 311-316. doi: 10.2323/jgam.44.311

Catzeddu, P., Mura, E., Parente, E., Sanna, M., and Farris, G. A. (2006). Molecular characterization of lactic acid bacteria from sourdough breads produced in Sardinia (Italy) and multivariate statistical analyses of results. Syst. Appl. Microbiol. 29, 138-144. doi: 10.1016/j.syapm.2005.07.013

Chahrour, W., Merzouk, Y., Henni, J. E., Haddaji, M., and Kihal, M. (2013). Screening and identification of lactic acid bacteria isolated from sorghum silage processes in west Algeria. Afr. J. Biotechnol. 12, 1703-1709. doi: 10.5897/AJB2012.9911

Chang, C.-H., Chena, Y.-S., and Yanagida, F. (2011). Isolation and characterisation of lactic acid bacteria from yan-jiang (fermented ginger), a traditional fermented food in Taiwan. J. Sci. Food Agric. 91, 1746-1750. doi: 10.1002/jsfa.4364

Chao, S. H., Tomii, Y., Watanabe, K., and Tsai, Y. C. (2008). Diversity of lactic acid bacteria in fermented brines used to make stinky tofu. Int. J. Food Microbiol. 123, 134-141. doi: 10.1016/j.ijfoodmicro.2007.12.010

Chao, S. H., Wu, R. J., Watanabe, K., and Tsai, Y. C. (2009). Diversity of lactic acid bacteria in suan-tsai and fu-tsai, traditional fermented 
mustard products of Taiwan. Int. J. Food Microbiol. 135, 203-210. doi: 10.1016/j.ijfoodmicro.2009.07.032

Chelo, I. M., Zé-Zé, L., and Tenreiro, R. (2010). Genome diversity in the genera Fructobacillus, Leuconostoc and Weissella determined by physical and genetic mapping. Microbiology 156, 420-430. doi: 10.1099/mic.0.028308-0

Chen, C., Chen, X., Jiang, M., Rui, X., Li, W., and Dong, M. (2014a). A newly discovered bacteriocin from Weissella hellenica D1501 associated with Chinese Dong fermented meat (Nanx Wudl). Food Control 42, 116-124. doi: 10.1016/j.foodcont.2014.01.031

Chen, C., Rui, X., Lu, Z., Li, W., and Dong, M. (2014b). Enhanced shelf-life of tofu by using bacteriocinogenic Weissella hellenica D1501 as bioprotective cultures. Food Control 46, 203-209. doi: 10.1016/j.foodcont.2014.05.004

Chen, Y. S., Wu, H. C., Lo, H. Y., Lin, W. C., Hsu, W. H., Lin, C. W., et al. (2012). Isolation and characterisation of lactic acid bacteria from jiang-gua (fermented cucumbers), a traditional fermented food in Taiwan. J. Sci. Food Agric. 92, 2069-2075. doi: 10.1002/jsfa.5583

Chen, Y. S., Yanagida, F., and Shinohara, T. (2005). Isolation and identification of lactic acid bacteria from soil using an enrichment procedure. Lett. Appl. Microbiol. 40, 195-200. doi: 10.1111/j.1472-765X.2005.01653.x

Cho, J., Lee, D., Yang, C., Jeon, J., Kim, J., and Han, H. (2006). Microbial population dynamics of kimchi, a fermented cabbage product. FEMS Microbiol. Lett. 257, 262-267. doi: 10.1111/j.1574-6968.2006.00186.x

Cho, K. T., Richardson, M. M., Kirkbride, P. K., McNevin, D., Nelson, M., Pianca, D., et al. (2014). Recovery and identification of bacterial DNA from illicit drugs. Forensic Sci. Int. 235, 78-85. doi: 10.1016/j.forsciint.2013.12.006

Choi, H. J., Cheigh, C. I., Kim, S. B., Lee, J. C., Lee, D. W., Choi, S. W., et al. (2002). Weissella kimchi sp. nov., a novel lactic acid bacterium from kimchi. Int. J. Syst. Evol. Microbiol. 52, 507-511. doi: 10.1099/ijs.0.01957-0

Chun, J., Kim, G. M., Lee, K. W., Choi, I. D., Kwon, G. H., Park, J. Y., et al. (2007). Conversion of isoflavone glucosides to aglycones in soymilk by fermentation with lactic acid bacteria. J. Food Sci. 72, M39-M44. doi: 10.1111/j.17503841.2007.00276.x

Cocolin, L., Dolci, P., Rantsiou, K., Urso, R., Cantoni, C., and Comi, G. (2009). Lactic acid bacteria ecology of three traditional fermented sausages produced in the North of Italy as determined by molecular methods. Meat Sci. 82, 125-132. doi: 10.1016/j.meatsci.2009.01.004

Coda, R., Di Cagno, R., Gobbetti, M., and Rizzello, C. G. (2014). Sourdough lactic acid bacteria: exploration of non-wheat cereal-based fermentation. Food Microbiol. 37, 51-58. doi: 10.1016/j.fm.2013.06.018

Coda, R., Nionelli, L., Rizzello, C. G., De Angelis, M., Tossut, P., and Gobbetti, M. (2010). Spelt and emmer flours: characterization of the lactic acid bacteria microbiota and selection of mixed starters for bread making. J. Appl. Microbiol. 108, 925-935. doi: 10.1111/j.1365-2672.2009.04497.x

Collins, M. D., Samelis, J., Metaxopoulos, J., and Wallbanks, S. (1993). Taxonomic studies on some Leuconostoc-like organisms from fermented sausages: description of a new genus Weissella for the Leuconostoc paramesenteroides group of species. J. Appl. Bacteriol. 75, 595-603. doi: 10.1111/j.1365-2672.1993.tb01600.x

Corsetti, A., Lavermicocca, P., Morea, M., Baruzzi, F., Tosti, N., and Gobbetti, M. (2001). Phenotypic and molecular identification and clustering of lactic acid bacteria and yeasts from wheat (species Triticum durum and Triticum aestivum) sourdoughs of Southern Italy. Int. J. Food Microbiol. 64, 95-104. doi: 10.1016/S0168-1605(00)00447-5

Costa, F. A. A., Leal, C. A. G., Schuenker, N. D., Leite, R. C., and Figueiredo, H. C. P. (2015). Characterization of Weissella ceti infections in Brazilian rainbow trout, Oncorhynchus mykiss (Walbaum), farms and development of an oil-adjuvanted vaccine. J. Fish Dis. 38, 295-302. doi: 10.1111/jfd.12236

De Bruyne, K., Camu, N., De Vuyst, L., and Vandamme, P. (2010). Weissella fabaria sp. nov., from a Ghanaian cocoa fermentation. Int. J. Syst. Evol. Microbiol. 60, 1999-2005. doi: 10.1099/ijs.0.019323-0

De Bruyne, K., Camu, N., Lefebvre, K., De Vuyst, L., and Vandamme, P. (2008). Weissella ghanensis sp. nov., isolated from a Ghanaian cocoa fermentation. Int. J. Syst. Evol. Microbiol. 58, 2721-2725. doi: 10.1099/ijs.0. 65853-0

De Man, J. C., Rogosa, M., and Sharpe, M. E. (1960). A medium for the cultivation of lactobacilli. J. Appl. Bacteriol. 23, 130-135. doi: 10.1111/j.13652672.1960.tb00188.x

Desai, A. R., Links, M. G., Collins, S. A., Mansfield, G. S., Drew, M. D., Van Kessel, A. G., et al. (2012). Effects of plant-based diets on the distal gut microbiome of rainbow trout (Oncorhynchus mykiss). Aquaculture 350, 134-142. doi: 10.1016/j.aquaculture.2012.04.005

De Vuyst, L., Schrijvers, V., Paramithiotis, S., Hoste, B., Vancanneyt, M., Swings, J., et al. (2002). The biodiversity of lactic acid bacteria in Greek traditional wheat sourdoughs is reflected in both composition and metabolite formation. Appl. Environ. Microbiol. 68, 6059-6069. doi: 10.1128/AEM.68.12.60596069.2002

Di Cagno, R., De Angelis, M., Limitone, A., Minervini, F., Carnevali, P., Corsetti, A., et al. (2006). Glucan and fructan production by sourdough Weissella cibaria and Lactobacillus plantarum. J. Agric. Food Chem. 54, 9873-9881. doi: $10.1021 /$ jf061393+

Di Cagno, R., Minervini, G., Rizzello, C. G., De Angelis, M., and Gobbetti, M. (2011). Effect of lactic acid fermentation on antioxidant, texture, color and sensory properties of red and green smoothies. Food Microbiol. 28, 1062-1071. doi: 10.1016/j.fm.2011.02.011

Di Cagno, R., Surico, R. F., Minervini, G., De Angelis, M., Rizzello, C. G., and Gobbetti, M. (2009b). Use of autochthonous starters to ferment red and yellow peppers (Capsicum annum L.) to be stored at room temperature. Int. J. Food Microbiol. 130, 108-116. doi: 10.1016/j.ijfoodmicro.2009.01.019

Di Cagno, R., Surico, R. F., Paradiso, A., De Angelis, M., Salmon, J. C., Buchin, S., et al. (2009a). Effect of autochthonous lactic acid bacteria starters on health promoting and sensory properties of tomato juices. Int. J. Food Microbiol. 128, 473-483. doi: 10.1016/j.ijfoodmicro.2008.10.017

Di Cagno, R., Surico, R. F., Siragusa, S., De Angelis, M., Paradiso, A., Minervini, F., et al. (2008). Selection and use of autochthonous mixed starter for lactic acid fermentation of carrots, French beans or marrows. Int. J. Food Microbiol. 127, 220-228. doi: 10.1016/j.ijfoodmicro.2008.07.010

Dicks, L. M., Fraser, T., ten Doeschate, K., and van Reenen, C. A. (2009). Lactic acid bacteria population in children diagnosed with human immunodeficiency virus. J. Paediatr. Child Health 45, 567-572. doi: 10.1111/j.14401754.2009.01566.x

Dicks, L. M. T. (1995). Relatedness of Leuconostoc species of the Leuconostoc sensu stricto line of descent, Leuconostoc oenos and Weissella paramesenteroides revealed by numerical analysis of total soluble cell protein patterns. Syst. Appl. Microbiol. 18, 99-102. doi: 10.1016/S0723-2020(11)80455-8

Diez, A. M., Björkroth, J., Jaime, I., and Rovira, J. (2009). Microbial, sensory and volatile changes during the anaerobic cold storage of morcilla de Burgos previously inoculated with Weissella viridescens and Leuconostoc mesenteroides. Int. J. Food Microbiol. 131, 168-177. doi: 10.1016/j.ijfoodmicro.2009.02.019

Elavarasi, V., Pugazhendhi, A., Poornima Priyadharsani, T. K., Valsala, H., and Thamaraiselvi, K. (2014). Screening and characterization of Weissella cibaria isolated from food source for probiotic properties. Int. J. Comp. Appl. 1, 29-32.

Emerenini, E. C., Afolabi, O. R., Okolie, P. I., and Akintokun, A. K. (2014). In vitro studies on antimicrobial activities of lactic acid bacteria isolated from fresh vegetables for biocontrol of tomato pathogens. Brit. Microbiol. Res. J. 4, 351-359. doi: 10.9734/BMRJ/2014/5423

Endo, A., Futagawa-Endo, Y., Kawasaki, S., Dicks, L. M. T., Niimura, Y., and Okada, S. (2009). Sodium acetate enhances hydrogen peroxide production in Weissella cibaria. Lett. Appl. Microbiol. 49, 136-141. doi: 10.1111/j.1472765X.2009.02633.x

Ennahar, S., and Cai, Y. (2004). Genetic evidence that Weissella kimchi Choi et al. 2002 is a later heterotypic synonym of Weissella cibaria Björkroth et al. 2002. Int. J. Syst. Evol. Microbiol. 54, 463-465. doi: 10.1099/ijs. 0.02783-0

Espeche, M. C., Otero, M. C., Sesma, F., and Nader-Macias, M. E. (2009). Screening of surface properties and antagonistic substances production by lactic acid bacteria isolated from the mammary gland of healthy and mastitic cows. Vet. Microbiol. 135, 346-357. doi: 10.1016/j.vetmic.2008.09.078

Fairfax, M. R., Lephart, P. R., and Salimnia, H. (2014). Weissella confusa: problems with identification of an opportunistic pathogen that has been found in fermented foods and proposed as a probiotic. Front. Microbiol. 5:254. doi: 10.3389/fmicb.2014.00254

Fhoula, I., Najjari, A., Turki, Y., Jaballah, S., Boudabous, A., and Ouzari, H. (2013). Diversity and antimicrobial properties of lactic acid bacteria isolated from rhizosphere of olive trees and desert truffles of Tunisia. Biomed. Res. Int. 2013:405708. doi: 10.1155/2013/405708

Figueiredo, H. C., Costa, F. A., Leal, C. A., Carvalho-Castro, G. A., and Leite, R. C. (2012). Weissella sp. outbreaks in commercial rainbow trout 
(Oncorhynchus mykiss) farms in Brazil. Vet. Microbiol. 156, 359-366. doi: 10.1016/j.vetmic.2011.11.008

Flaherty, J. D., Levett, P. N., Dewhirst, F. E., Troe, T. E., Warren, J. R., and Johnson, S. (2003). Fatal case of endocarditis due to Weissella confusa. J. Clin. Microbiol. 41, 2237- 2239. doi: 10.1128/JCM.41.5.2237-2239.2003

Fuka, M. M., Wallisch, S., Engel, M., Welzl, G., Havranek, J., and Schloter, M. (2013). Dynamics of bacterial communities during the ripening process of different Croatian cheese types derived from raw ewe's milk cheeses. PLoS ONE 8:e80734. doi: 10.1371/journal.pone.0080734

Fusco, V., Quero, G. M., Stea, G., Morea, M., and Visconti, A. (2011). Novel PCR based identification of Weissella confusa using an AFLP-derived marker. Int. J. Food Microbiol. 145, 437-443. doi: 10.1016/j.ijfoodmicro.2011.01.015

Galle, S., Schwab, C., Arendt, E., and Gänzle, M. (2010). Exopolysaccharideforming Weissella strains as starter cultures for sorghum and wheat sourdoughs. J. Agric. Food Chem. 58, 5834-5841. doi: 10.1021/jf1002683

Galle, S., Schwab, C., Dal Bello, F., Coffey, A., Gänzle, M. G., and Arendt, E. K. (2012). Influence of in-situ synthesized exopolysaccharides on the quality of gluten-free sorghum sourdough bread. Int. J. Food Microbiol. 155, 105-112. doi: 10.1016/j.ijfoodmicro.2012.01.009

Garvie, E. I. (1967). The growth factor and amino acid requirements of species of the genus Leuconostoc including Leuconostoc paramesenteroides (sp. nov.) and Leuconostoc oenos. J. Gen. Microbiol. 48, 439-447. doi: 10.1099/00221287-483-439

Gomathi, S., Sasikumar, P., Anbazhagan, K., Sasikumar, S., Kavitha, M., Selvi, M. S., et al. (2014). Screening of indigenous oxalate degrading lactic acid bacteria from human faeces and South Indian fermented foods: assessment of probiotic potential. ScientificWorldJournal 2014:648059. doi: 10.1155/2014/648059

González-Quijano, G. K., Dorantes-Alvarez, L., Hernández-Sánchez, H., JaramilloFlores, M. E., de Jesús Perea-Flores, M., Vera-Ponce de León, A., et al. (2014). Halotolerance and survival kinetics of lactic acid bacteria isolated from jalapeño pepper (Capsicum annuum L.) fermentation. J. Food Sci. 79, M1545-M1553. doi: 10.1111/1750-3841.12498

Graef, E. M., Devriese, L. A., Baele, M., Vancanneyt, M., Swings, J., Haesebrouck, F., et al. (2005). Identification of enterococcal, streptococcal and Weissellaspecies in the faecal flora of individually owned dogs. J. Appl. Microbiol. 99, 348-353. doi: 10.1111/j.1365-2672.2005.02588.x

Green, M., Barbadora, K., and Michaels, M. (1991). Recovery of vancomycinresistant Gram-positive cocci from pediatric liver transplant recipients. J. Clin. Microbiol. 29, 2503-2508.

Green, M., Wadowsky, R. M., and Barbadora, K. (1990). Recovery of vancomycinresistant gram-positive cocci from children. J. Clin. Microbiol. 28, 484-488.

Hammes, W. P., and Vogel, R. F. (1995). "The genus Lactobacillus," in The Genera of Lactic Acid Bacteria, eds B. J. B. Wood and W. Holzapfel (Glasgow: Blackie Academic and Professional), 19-54.

Harlan, N. P., Kempker, R. R., Parekh, S. M., Burd, E. M., and Kuhar, D. T. (2011). Weissella confusa bacteremia in a liver transplant patient with hepatic artery thrombosis. Transpl. Infect. Dis. 13, 290-293. doi: 10.1111/j.13993062.2010.00579.x

Hill, C., Guarner, F., Reid, G., Gibson, G. R., Merenstein, D. J., Pot, B., et al. (2014). The International Scientific Association for Probiotics and Prebiotics consensus statement on the scope and appropriate use of the term probiotic. Nature Rev. Gastro. Hepatol. 11, 506-514. doi: 10.1038/nrgastro.2014.66

Holzapfel, W., and Kandler, O. (1969). Zur Taxonomie der Gattung Lactobacillus Beijerinck. VI. Lactobacillus coprophilus subsp. confusu nov. subsp., eine neue Unterart der Untergattung Betabacterium. Zentralbl. Bakteriol. Parasitenk. Infektionskr. Abt. 123, 657-666.

Holzapfel, W. H., and van Wyk, E. P. (1982). Lactobacillus kandleri sp. nov., a new species of the subgenus Betabacterium with glycine in the peptidoglycan. Zentrbl. Bakteriol. Parasitenkd. Infektkrankh. Hyg. C3, 495-502.

Holzapfel, W. H., and van Wyk, E. P. (1983). Validation List $\mathrm{N}^{\circ}$ 10. Int. J. Sist. Bacteriol. 33, 438-440.

Hovda, M. B., Fontanillas, R., McGurk, C., Obach, A., and Rosnes, J. T. (2012). Seasonal variations in the intestinal microbiota of farmed Atlantic salmon (Salmo salar L.). Aquacult. Res. 43, 154-159. doi: 10.1111/j.1365-2109.2011. 02805.x

Iacumin, L., Andyanto, D., Manzano, M., Comuzzo, P., and Comi, G. (2014). A case of spoilage in wurstel sold in an Italian supermarket. Food Control 43, 245-250. doi: 10.1016/j.foodcont.2014.03.021
Immerzeel, P., Falck, P., Galbe, M., Adlercreutz, P., Nordberg Karlsson, E., and Stålbrand, H. (2014). Extraction of water-soluble xylan from wheat bran and utilization of enzymatically produced xylooligosaccharides by Lactobacillus, Bifidobacterium and Weissella spp. LWT Food Sci. Technol. 56, 321-327. doi: 10.1016/j.lwt.2013.12.013

Isono, Y., Shingu, I., and Shimizu, S. (1994). Identification and characteristics of lactic acid bacteria isolated from Maasai fermented milk in northern Tanzania. Biosci. Biotechnol. Biochem. 58, 660-664. doi: 10.1271/bbb.58.660

Jang, J., Kim, B., Lee, J., Kim, J., Jeong, G., and Han, H. (2002). Identification of Weissella species by the genus-specific amplified ribosomal DNA restriction analysis. FEMS Microbiol. Lett. 212, 29-34. doi: 10.1111/j.15746968.2002.tb11240.x

Jansa, C., Bugnarda, J., Murigu Kamau Njagea, P., Lacroixa, C., and Meile, L. (2012). Lactic acid bacteria diversity of African raw and fermented camel milk products reveals a highly competitive, potentially healththreatening predominant microflora. LWT Food Sci. Technol. 47, 371-379. doi: 10.1016/j.lwt.2012.01.034

Jeong, S. H., Jung, J. Y., Lee, S. H., Jin, H. M., and Jeon, C. O. (2013).Microbial succession and metabolite changes during fermentation of dongchimi, traditional Korean watery kimchi. Int. J. Food Microbiol. 164, 46-53. doi: 10.1016/j.ijfoodmicro.2013.03.016

Jeurink, P. V., van Bergenhenegouwen, J., Jiménez, E., Knippels, L. M., Fernández, L., Garssen, J., et al. (2013). Human milk: a source of more life than we imagine. Benef. Microbes. 4, 17-30. doi: 10.3920/BM2012.0040

Jin, L., Tao, L., Pavlova, S. I., So, J. S., Kiwanuka, N., Namukwaya, Z., et al. (2007). Species diversity and relative abundance of vaginal lactic acid bacteria from women in Uganda and Korea. J. Appl. Microbiol. 102, 1107-1115. doi: 10.1111/j.1365-2672.2006.03147.x

Justé A., Malfliet, S., Waud, M., Crauwels, S., De Cooman, L., Aerts, G., et al. (2014). Bacterial community dynamics during industrial malting, with an emphasis on lactic acid bacteria. Food Microbiol. 39, 39-46. doi: 10.1016/j.fm.2013.10.010

Kajala, I., Shi, Q., Nyyssölä. A., Maina, N. H., Hou, Y., Katina, K., et al. (2015). Cloning and characterization of a Weissella confusa dextransucrase and its application in high fibre baking. PLoS ONE 10:e0116418. doi: 10.1371/journal.pone. 0116418

Kandler, O., and Abo-Elnaga, I. G. (1966). Zur Taxonomie der Gattung Lactobacillus Beijerinck IV. L. corynoides ein Synonym von L. viridescens. Zbl. Bakt. Abt. 120, 753-759.

Kandler, O., Schillinger, U., and Weiss, N. (1983). Lactobacillus halotolerans sp. nov., nom. rev. and Lactobacillus minor sp. nov., nom. rev. Syst. Appl. Microbiol. 4, 280-285. doi: 10.1016/S0723-2020(83)80056-3

Kandler, O., and Weiss, N. (1986). "Genus Lactobacillus," in Bergey's Manual of Systematic Bacteriology, Vol. 2, eds P. H. A. Sneath and J. G. Holz (Baltimore: William and Wilkins), 1209-1234.

Kang, H. K., Oh, J. S., and Kim, D. (2009). Molecular characterization and expression analysis of the glucansucrase DSRWC from Weissella cibaria synthesizing a $\alpha$-(1-6) glucan. FEMS Microbiol. Lett. 292, 33-41. doi: 10.1111/j.15746968.2008.01460.x

Kang, M. S., Chung, J., Kim, S. M., Yang, K. H., and Oh, J. S. (2006a). Effect of Weissella cibaria isolates on the formation of Streptococcus mutans biofilm. Caries Res. 40, 418-425. doi: 10.1159/000094288

Kang, M. S., Kim, B. G., Chung, J., Lee, H. C., and Oh, J. S. (2006b). Inhibitory effect of Weissella cibaria isolates on the production of volatile sulphur compounds. J. Clin. Periodontol. 33, 226-232. doi: 10.1111/j.1600-051X.2006. 00893.x

Kang, M.-S., Kim, S.-M., Lee, H.-C., Lim, H.-S., and Oh, J.-S.,(2012). Comparison of temperature and additives affecting the stability of probiotic Weissella cibaria. Chonnam Med. J. 48, 159-163. doi: 10.4068/cmj.2012.48.3.159

Kang, M.-S., Lim, H.-S., Kim, S.-M., Lee, H.-C., and Oh, J.-S.,(2011). Effect of Weissella cibaria on Fusobacterium nucleatum -induced interleukin-6 and interleukin-8 production in KB cells. J. Bacteriol. Virol. 41, 9-18. doi: 10.4167/jbv.2011.41.1.9

Kang, M. S., Na, H. S., and Oh, J. S. (2005). Coaggregation ability of Weissella cibaria isolates with Fusobacterium nucleatum and their adhesiveness to epithelial cells. FEMS Microbiol. Lett. 253, 323-329. doi: 10.1016/j.femsle.2005.10.002

Katina, K., Maina, N. H., Juvonen, R., Flander, L., Johansson, L., Virkki, L., et al. (2009). In situ production and analysis of Weissella confusa dextran in wheat sourdough. Food Microbiol. 26, 734-743. doi: 10.1016/j.fm.2009.07.008 
Kim, T. W., Lee, J. H., Kim, S. E., Park, M. H., Chang, H. C., and Kim, H. Y. (2009). Analysis of microbial communities in doenjang, a Korean fermented soybean paste, using nested PCR-denaturing gradient gel electrophoresis. Int. J. Food Microbiol. 131, 265-271. doi: 10.1016/j.ijfoodmicro.2009.03.001

Kline, L., and Sugihara, T. F. (1971). Microorganisms of the San Francisco sourdough process. II. Isolation and characterization of undescribed bacterial species responsible for souring activity. Appl. Microbiol. 21, 459-465.

Koort, J., Coenye, T., Santos, E. M., Molinero, C., Jaime, I., Rovira, J., et al. (2006). Diversity of Weissella viridescens strains associated with "Morcilla de Burgos." Int. J. Food Microbiol. 109, 164-168. doi: 10.1016/j.ijfoodmicro.2006. 01.021

Kopermsuba, P., and Yunchalard, S. (2010). Identification of lactic acid bacteria associated with the production of plaa-som, a traditional fermented fish product of Thailand. Int. J. Food Microbiol. 138, 200-204. doi: 10.1016/j.ijfoodmicro.2010.01.024

Korkeala, H., and Björkroth, K. J. (1997). Spoilage and contamination of vacuum packaged cooked sausages: a review. J. Food Prot. 60, 724-731.

Kostinek, M., Specht, I., Edward, V. A., Pintb, C., Egounlety, M., Sossa, C., et al. (2007). Characterisation and biochemical properties of predominant lactic acid bacteria from fermenting cassava for selection as starter cultures. Int. J. Food Microbiol. 114, 342-351. doi: 10.1016/j.ijfoodmicro.2006.09.029

Kostinek, M., Specht, I., Edward, V. A., Schillinger, U., Hertel, C., Holzapfel, W. H., et al. (2005). Diversity and technological properties of predominant lactic acid bacteria from fermented cassava used for the preparation of Gari, a traditional African food. Syst. Appl. Microbiol. 28, 527-540. doi: 10.1016/j.syapm.2005.03.001

Kulwichit, W., Nilgate, S., Chatsuwan, T., Krajiw, S., Unhasuta, C., and Chongthaleong, A. (2007). Accuracies of Leuconostoc phenotypic identification: a comparison of API systems and conventional phenotypic assays. BMC Infect. Dis. 7:69. doi: $10.1186 / 1471-2334-7-69$

Kulwichit, W., Nilgate, S., Krajiw, S., Unhasuta, C., Chatsuwan, T., and Chongthaleong, A. (2008). "Weissella spp.: lactic acid bacteria emerging as a human pathogen. Abstract number: P1847," in 18th European Congress of Clinical Microbiology and Infectious Diseases (Barcelona).

Kumar, A., Augustine, D., Sudhindran, S., Kurian, A. M., Dinesh, K. R., Karim, S., et al. (2011). Weissella confusa: a rare cause of vancomycinresistant Gram-positive bacteraemia. J. Med. Microbiol. 60, 1539-1541. doi: 10.1099/jmm.0.027169-0

Lahtinen, S., Ouwehand, A. C., Salminen, S., and Von Wright, A. (eds.). (2012). Lactic Acid Bacteria-Microbiological and Functional Aspects, 4th Edn. Boca Raton, FL: CRC Press (Taylor and Francis Group).

Lan, W. T., Chen, Y., and Yanagida, F. (2009). Isolation and characterization of lactic acid bacteria from Yan-dong-gua (fermented waxgourd), a traditional fermented food in Taiwan. J. Biosci. Bioeng. 108, 484-487. doi: 10.1016/j.jbiosc.2009.06.009

Lawhon, S. D., Lopez, F. R., Joswig, A., Black, H. C., Watts, A. E., Norman, T. E., et al. (2014). Weissella confusa septicemia in a foal. J. Vet. Diagn. Invest. 26, 150-153. doi: 10.1177/1040638713510516

Lee, J. S., Heo, G. Y., Lee, J. W., Oh, Y. J., Park, J. A., Park, Y. H., et al. (2005). Analysis of kimchi microflora using denaturing gradient gel electrophoresis. Int. J. Food Microbiol. 102, 143-150. doi: 10.1016/j.ijfoodmicro.2004.12.010

Lee, J. S., Lee, K. C., Ahn, J. S., Mheen, T. I., Pyun, Y. R., and Park, Y. H. (2002). Weissella koreensis sp. nov., isolated from kimchi. Int. J. Syst. Evol. Microbiol. 52, 1257-1261. doi: 10.1099/ijs.0.02074-0

Lee, K. W., Park, J. Y., Jeong, H. R., Heo, H. J., Han, N. S., and Kim, J. H. (2012). Probiotic properties of Weissella strains isolated from human faeces. Anaerobe 18, 96-102. doi: 10.1016/j.anaerobe.2011.12.015

Lee, M. R., Huang, Y. T., Liao, C. H., Lai, C. C., Lee, P. I., and Hsueh, P. R. (2011). Bacteraemia caused by Weissella confusa at a university hospital in Taiwan 1997-2007. Clin. Microbiol. Infect. 17, 1226-1231. doi: 10.1111/j.14690691.2010.03388.x

Lee, W., Cho, S.-M., Kim, M., Ko, Y.-G., Yong, D., and Lee, K. (2013). Weissella confusa bacteremia in an immune-competent patient with underlying intramural hematomas of the aorta. Ann. Lab. Med. 33, 459-462. doi: 10.3343/alm.2013.33.6.459

Lee, Y. (2005). Characterization of Weissella kimchii PL9023 as a potential probiotic for women. FEMS Microbiol. Lett. 250, 157-162. doi: 10.1016/j.femsle.2005.07.009
Leisner, J. J., Pot, B., Christensen, H., Rusul, G., Olsen, J. E., Wee, B. W., et al. (1999). Identification of lactic acid bacteria from chili bo, a malaysian food ingredient. Appl. Environ. Microbiol. 65, 599-605.

Leong, K. H., Chen, Y. S., Lin, Y. H., Pan, S. F., Yu, B., Wu, H. C., et al. (2013). Weissellicin L, a novel bacteriocin from sian-sianzih-isolated Weissella hellenica 4-7. J. Appl. Microbiol. 115, 70-76. doi: 10.1111/jam.12218

Liu, C. J. I., Gong, F. M., Li, X. R., Li, H. Y., Zhang, Z. H., Feng, Y., et al. (2012). Natural populations of lactic acid bacteria in douchi from Yunnan Province, China. J. Zhejiang Univ. Sci. B. 13, 298-306. doi: 10.1631/jzus.B1100221

Liu, J. Y., Li, A. H., Ji, C., and Yang, W. M. (2009). First description of a novel Weissella species as an opportunistic pathogen for rainbow trout Oncorhynchus mykiss (Walbaum) in China. Vet. Microbiol. 136, 314-320. doi: 10.1016/j.vetmic.2008.11.027

Magnusson, J., Jonsson, H., Schnurer, J., and Roos, S. (2002). Weissella soli sp. nov., a lactic acid bacterium isolated from soil. Int. J. Syst. Evol. Microbiol. 52, 831-834. doi: 10.1099/ijs.0.02015-0

Maina, N. H., Juvonen, M., Domingues, R. M., Virkki, L., Jokela, J., and Tenkanen, M. (2013). Structural analysis of linear mixed-linkage glucooligosaccharides by tandem mass spectrometry. Food Chem. 136, 1496-1507. doi: 10.1016/j.foodchem.2012.09.075

Maina, N. H., Pitkänen, L., Heikkinen, S., Tuomainen, P., Virkki, L., and Tenkanen, $M$. (2014). Challenges in analysis of high-molar mass dextrans: comparison of HPSEC, AsFlFFF and DOSY NMR spectroscopy. Carbohydr. Polym. 99, 199-207. doi: 10.1016/j.carbpol.2013.08.021

Maina, N. H., Tenkanen, M., Maaheimo, H., Juvonen, R., and Virkki, L. (2008). NMR spectroscopic analysis of exopolysaccharides produced by Leuconostoc citreum and Weissella confusa. Carbohydr. Res. 343, 1446-1455. doi: 10.1016/j.carres.2008.04.012

Maina, N. H., Virkki, L., Pynnönen, H., Maaheimo, H., and Tenkanen, M. (2011). Structural analysis of enzyme-resistant isomaltooligosaccharides reveals the elongation of $\alpha-(1 \rightarrow 3)$-linked branches in Weissella confusa dextran. Biomacromolecules 12, 409-418. doi: 10.1021/bm1011536

Makarova, K., Slesarev, A., Wolf, Y., Sorokin, A., Mirkin, B., Koonin, E., et al. (2006). Comparative genomics of the lactic acid bacteria. Proc. Natl. Acad. Sci. U.S.A. 103, 15611-15616. doi: 10.1073/pnas.0607117103

Malang, S. K., Maina, N. H., Schwab, C., Tenkanen, M., and Lacroix, C. (2015). Characterization of exopolysaccharide and ropy capsular polysaccharide formation by Weissella. Food Microbiol. 46, 418-427. doi: 10.1016/j.fm.2014.08.022

Malik, A. (2012). Molecular cloning and in silico characterization of fructansucrase gene from Weissella confusa MBFCNC-2(1) isolated from local beverage. Asia-Pacific J. Mol. Biol. Biotechnol. 20, 33-42. Available online at: http://www.myjurnal.my/public/article-view.php?id=62644

Malik, A., Radji, M., Kralj, S., and Dijkhuizen, L. (2009). Screening of lactic acid bacteria from Indonesia reveals glucansucrase and fructansucrase genes in two different Weissella confusa strains from soya. FEMS Microbiol. Lett. 300, 131-138. doi: 10.1111/j.1574-6968.2009.01772.x

Martín, R., Heilig, H. G., Zoetendal, E. G., Jiménez, E., Fernández, L., Smidt, H., et al. (2007a). Cultivation-independent assessment of the bacterial diversity of breast milk among healthy women. Res. Microbiol. 158, 31-37. doi: 10.1016/j.resmic.2006.11.004

Martín, R., Heilig, H. G., Zoetendal, E. G., Smidt, H., and Rodríguez, J. M. (2007b). Diversity of the Lactobacillus group in breast milk and vagina of healthy women and potential role in the colonization of the infant gut. J. Appl. Microbiol. 103, 2638-2644. doi: 10.1111/j.1365-2672.2007.03497.x

Martín, R., Olivares, M., Pérez, M., Xaus, J., Torre, C., Fernández, L., et al (2010). Identification and evaluation of the probiotic potential of lactobacilli isolated from canine milk. Vet. J. 185, 193-198. doi: 10.1016/j.tvjl.2009. 04.014

Mas, M., Tabla, R., Moriche, J., Roa, I., Gonzalez, J., Rebollo, J. E., et al. (2002). Ibores goat's milk cheese: microbiological and physicochemical changes throughout ripening. Le Lait 82, 579-587. doi: 10.1051/lait:2002034

Masoud, W., Vogensen, F. K., Lillevang, S., Abu Al-Soud, W., Sørensen, S. J., and Jakobsen, M. (2012).The fate of indigenous microbiota, starter cultures, Escherichia coli, Listeria innocua and Staphylococcus aureus in Danish raw milk and cheeses determined by pyrosequencing and quantitative real time (qRT)-PCR. Int. J. Food Microbiol. 153, 192-202. doi: 10.1016/j.ijfoodmicro.2011.11.014 
Masuda, Y., Zendo, T., Sawa, N., Perez, R. H., Nakayama, J., and Sonomoto, K. (2012). Characterization and identification of weissellicin $Y$ and weissellicin $M$, novel bacteriocins produced by Weissella hellenica QU 13. J. Appl. Microbiol. 112, 99-108. doi: 10.1111/j.1365-2672.2011.05180.x

Mathara, J. M., Schillinger, U., Kutima, P. M., Mbugua, S. K., and Holzapfel, W. H. (2004). Isolation, identification and characterisation of the dominant microorganisms of kulenaoto: the Maasai traditional fermented milk in Kenya. Int. J. Food Microbiol. 94, 269-278. doi: 10.1016/j.ijfoodmicro.2004. 01.008

Medford, R., Patel, S. N., and Evans, G. A. (2014). A confusing case-Weissella confusa prosthetic joint infection: a case report and review of the literature. Can. J. Infect. Dis. Med. Microbiol. 25, 173-175.

Merivirta, L. O., Koort, J. M., Kivisaari, M., Korkeala, H., and Björkroth, K. J. (2005). Developing microbial spoilage population in vacuum-packaged charcoal-broiled European river lamprey (Lampetra fluviatilis). Int. J. Food Microbiol. 101, 145-152. doi: 10.1016/j.ijfoodmicro.2004.10.046

Merzouk, Y., Chahrour, W., Zarour, K., Zergui, A., Saidi, N., Henni Jamal, E., et al. (2013). Physico-chemical and microbiological analysis of Algerian raw camel's milk and identification of predominating thermophilic lactic acid bacteria. J. Food Sci. Engin. 3, 55-63.

Moon, Y. J., Soh, J. R., Yu, J. J., Sohn, H. S., Cha, Y. S., and Oh, S. H. (2012). Intracellular lipid accumulation inhibitory effect of Weissella koreensis OK1-6 isolated from Kimchi on differentiating adipocyte. J. Appl. Microbiol. 113, 652-658. doi: 10.1111/j.1365-2672.2012.05348.x

Moroni, A. V., Arendt, E. K., and Dal Bello, F. (2011). Biodiversity of lactic acid bacteria and yeasts in spontaneously-fermented buckwheat and teff sourdoughs. Food Microbiol. 28, 497-502. doi: 10.1016/j.fm.2010.10.016

Mugula, J. K., Nnko, A., Narvhus, J. A., and Sørhaug, T. (2003). Microbiological and fermentation characteristics of togwa, a Tanzanian fermented food. Int. J. Food Microbiol. 80, 187-199. doi: 10.1016/S0168-1605(02)00141-1

Muñoz-Atienza, E., Gómez-Sala, B., Araújo, C., Campanero, C., del Campo, R., Hernández, P. E., et al. (2013). Antimicrobial activity, antibiotic susceptibility and virulence factors of lactic acid bacteria of aquatic origin intended for use as probiotics in aquaculture. BMC Microbiol. 13:15. doi: 10.1186/1471-21 80-13-15

Muyanja, C. M., Narvhus, J. A., Treimo, J., and Langsrud, T. (2003). Isolation, characterisation and identification of lactic acid bacteria from bushera: a Ugandan traditional fermented beverage. Int. J. Food Microbiol. 80, 201-210. doi: 10.1016/S0168-1605(02)00148-4

Nam, H., Ha, M., Bae, O., and Lee, Y. (2002). Effect of Weissella confusa strain PL9001 on the adherence and growth of Helicobacter pylori. Appl. Environ. Microbiol. 68, 4642-4645. doi: 10.1128/AEM.68.9.4642-4645.2002

Nam, H., Whang, K., and Lee, Y. (2007). Analysis of vaginal lactic acid producing bacteria in healthy women. J. Microbiol. 45, 515-520.

Ndagano, D., Lamoureux, T., Dortu, C., Vandermoten, S., and Thonart, P. (2011). Antifungal activity of 2 lactic acid bacteria of the Weissella genus isolated from food. J. Food Sci. 76, M305-M311. doi: 10.1111/j.1750-3841.2011.02257.x

Nisiotou, A., Dourou, D., Filippousi, M. E., Banilas, G., and Tassou, C. (2014). Weissella uvarum sp. nov., isolated from wine grapes. Int. J. Syst. Evol. Microbiol. 64, 3885-3890. doi: 10.1099/ijs.0.066209-0

Nistal, E., Caminero, A., Vivas, S., Ruiz de Morales, J. M., Sáenz de Miera, L. E., Rodríguez-Aparicio, L. B., et al. (2012). Differences in faecal bacteria populations and faecal bacteria metabolism in healthy adults and celiac disease patients. Biochimie 94, 1724-1729. doi: 10.1016/j.biochi.2012.03.025

Niven, C. F. Jr., and Evans, J. B. (1957). Lactobacillus viridescens nov. spec., a heterofermentative species that produces a green discoloration of cured meat pigments. J. Bacteriol. 3, 758-759.

Oh, S. J., Shin, N.-R., Hyun, D.-W., Kim, P. S., Kim, J. Y., Kim, M.-S., et al. (2013). Weissella diestrammenae sp. nov., isolated from the gut of a camel cricket (Diestrammena coreana). Int. J. Syst. Evol. Microbiol. 63, 2951-2956. doi: 10.1099/ijs.0.047548-0

Olano, A., Chua, J., Schroeder, S., Minari, A., Lasalvia, M., and Hall, G. (2001). Weissella confusa (Basonym: Lactobacillus confusus) bacteremia: a case report. J. Clin. Microbiol. 39, 1604-1607. doi: 10.1128/JCM.39.4.1604-1607.2001

Ono, H., Nishio, S., Tsurii, J., Kawamoto, T., Sonomoto, K., and Nakayama, J. (2014). Monitoring of the microbiota profile in nukadoko, a naturally fermented rice bran bed for pickling vegetables. J. Biosci. Bioeng. 118, 520-525. doi: 10.1016/j.jbiosc.2014.04.017
Osimani, A., Garofalo, C., Aquilanti, L., Milanoviæ, V., and Clementi, F. (2015). Unpasteurised commercial boza as a source of microbial diversity. Int. J. Food Microbiol. 194C, 62-70. doi: 10.1016/j.ijfoodmicro.2014.11.011

Ouoba, L. I., Lei, V., and Jensen, L. B. (2008). Resistance of potential probiotic lactic acid bacteria and bifidobacteria of African and European origin to antimicrobials: determination and transferability of the resistance genes to other bacteria. Int. J. Food. Microbiol. 121, 217-224. doi: 10.1016/j.ijfoodmicro.2007.11.018

Ouoba, L. I. I., Nyanga-Koumou, C. A. G., Parkouda, C., Sawadogo, H., Kobawila, S. C., Keleke, S., et al. (2010). Genotypic diversity of lactic acid bacteria isolated from African traditional alkaline-fermented foods. J. Appl. Microbiol. 108, 2019-2029. doi: 10.1111/j.1365-2672.2009.04603.x

Padonou, S. W., Schillinger, U., Nielsen, D. S., Franz, C. M., Hansen, M., Hounhouigan, J. D., et al. (2010). Weissella beninensis sp. nov., a motile lactic acid bacterium from submerged cassava fermentations, and emended description of the genus Weissella. Int. J. Syst. Evol. Microbiol. 60, 2193-2198. doi: 10.1099/ijs.0.014332-0

Pal, A., Ramana, K. V., and Bawa, A. S. (2010). Simplification and optimization of deMan Rogosa Sharpe (MRS) medium for enhanced production of bacteriocin by Weissella paramesenteroides DFR-8. J. Food Sci Technol. 47, 258-265. doi: 10.1007/s13197-010-0040-2

Pang, H., Tan, Z., Qin, G., Wang, Y., Li, Z., Jin, Q., et al. (2012). Phenotypic and phylogenetic analysis of lactic acid bacteria isolated from forage crops and grasses in the Tibetan Plateau. J. Microbiol. 50, 63-71. doi: 10.1007/s12275-0121284-5

Pang, H., Zhang, M., Qin, G., Tan, Z., Li, Z., Wang, Y., et al. (2011). Identification of lactic acid bacteria isolated from corn stovers. Anim. Sci. J. 82, 642-653. doi: 10.1111/j.1740-0929.2011.00894.x

Papagianni, M. (2012). Effects of dissolved oxygen and pH levels on weissellin A production by Weissella paramesenteroides DX in fermentation. Bioprocess Biosyst. Eng. 35, 1035-1041. doi: 10.1007/s00449-012-0689-1

Papagianni, M., and Papamichael, E. M. (2011). Purification, amino acid sequence and characterization of the class IIa bacteriocin weissellin A, produced by Weissella paramesenteroides DX. Bioresour. Technol. 102, 6730-6734. doi: 10.1016/j.biortech.2011.03.106

Papagianni, M., and Papamichael, E. M. (2012). Production of the antimicrobial protein weissellin A by Weissella paramesenteroides DX in batch fermentations: the type of carbohydrate used as the C-source in the substrate affects the association of production with growth. Appl. Biochem. Biotechnol. 168, 1212-1222. doi: 10.1007/s12010-012-9851-0

Papagianni, M., and Sergelidis, D. (2013). Effects of the presence of the curing agent sodium nitrite, used in the production of fermented sausages, on bacteriocin production by Weissella paramesenteroides DX grown in meat simulation medium. Enzyme Microb. Technol. 53, 1-5. doi: 10.1016/j.enzmictec.2013.04.003

Papamanoli, E., Tzanetakis, N., Litopoulou-Tzanetaki, E., and Kotzekidou, P. (2003). Characterization of lactic acid bacteria isolated from a Greek dry-fermented sausage in respect of their technological and probiotic properties. Meat Sci. 65, 859-867. doi: 10.1016/S0309-1740(02) 00292-9

Park, J. A., Tirupathi Pichiah, P. B., Yu, J. J., Oh, S. H., Daily, J. W. III., and Cha, Y. S. (2012). Anti-obesity effect of kimchi fermented with Weissella koreensis OK1-6 as starter in high-fat diet-induced obese C57BL/6J mice. J. Appl. Microbiol. 113, 1507-1516. doi: 10.1111/jam.12017

Park, J. M., Shin, J. H., Lee, D. W., Song, J. C., Suh, H. J., Chang, U. J., et al. (2010). Identification of the lactic acid bacteria in Kimchi according to initial and over-ripened fermentation using PCR and 16S rRNA gene sequence analysis. Food Sci. Biotechnol. 19, 541-546. doi: 10.1007/s10068-0100075-1

Patel, A., Falck, P., Shah, N., Immerzeel, P., Adlercreutz, P., Stålbrand, H., et al (2013). Evidence for xylooligosaccharide utilization in Weissella strains isolated from Indian fermented foods and vegetables. FEMS Microbiol. Lett. 346, 20-28. doi: 10.1111/1574-6968.12191

Patel, S., and Goyal, A. (2011). Functional oligosaccharides: production, properties and applications. World J. Microbiol. Biotechnol. 27, 1119-1128. doi: 10.1007/s11274-010-0558-5

Pepe, O., Villani, F., and Coppola, S. (2001). Differential viable count of mixed starter cultures of lactic acid bacteria in doughs by using modified 
Chalmers medium. Microbiol. Res. 155, 351-354. doi: 10.1016/S0944-5013(01) 80015-X

Pereira, C. I., San Romão, M. V., Lolkema, J. S., and BarretoCrespo, M. T. (2009). Weissella halotolerans W22 combines arginine deiminase and ornithinedecarboxylation pathways and converts arginine to putrescine. J. Appl. Microbiol. 107, 1894-1902. doi: 10.1111/j.1365-2672.2009.04371.x

Ponnusamy, K., Choi, J. N., Kim, J., Lee, S. Y., and Lee, C. H. (2011). Microbial community and metabolomic comparison of irritable bowel syndrome faeces. J. Med. Microbiol. 60, 817-827. doi: 10.1099/jmm.0.028126-0

Pothakos, V., Taminiau, B., Huys, G., Nezer, C., Daube, G., and Devlieghere, F. (2014). Psychrotrophic lactic acid bacteria associated with production batch recalls and sporadic cases of early spoilage in Belgium between 2010 and 2014. Int. J. Food Microbiol. 191, 157-163. doi: 10.1016/j.ijfoodmicro.2014.09.013

Pringsulaka, O., Patarasinpaiboon, N., Suwannasai, N., Atthakor, W., and Rangsiruji, A. (2011). Isolation and characterisation of a novel Podoviridaephage infecting Weissella cibaria $\mathrm{N} 22$ from Nham, a Thai fermented pork sausage. Food Microbiol. 28, 518-525. doi: 10.1016/j.fm.2010.10.011

Rao, T. J., and Goyal, A. (2013a). Purification, optimization of assay, and stability studies of dextransucrase isolated from Weissella cibaria JAG8. Prep. Biochem. Biotechnol. 43, 329-341. doi: 10.1080/10826068.2012.737400

Rao, T. J., and Goyal, A. (2013b). A novel high dextran yielding Weissella cibaria JAG8 for cereal food application. Int. J. Food Sci. Nutr. 64, 346-354. doi: 10.3109/09637486.2012.734289

Rastall, R. A., and Gibson, G. R. (2014). Recent developments in prebiotics to selectively impact beneficial microbes and promote intestinal health. Curr. Opin. Biotechnol. 32C, 42-46. doi: 10.1016/j.copbio.2014.11.002

Rengpipat, S., Rueangruklikhit, T., and Piyatiratitivorakul, S. (2008). Evaluations of lactic acid bacteria as probiotics for juvenile seabass Lates calcarifer. Aquacult. Res. 39, 134-143. doi: 10.1111/j.1365-2109.2007.01864.x

Reuter, G. (1970). Laktobazillen und eng verwandte Mikroorganismen in Fleisch und Fleischerzeugnissen. 2. Mitteilung: Die Charakterisierung der isolierten Laktobazillenstämme. Fleischwirtschaft 7, 954-962.

Riebel, W., and Washington, J. (1990).Clinical and microbiologic characteristics of pediococci. J. Clin. Microbiol. 28, 1348-1355.

Robert, H., Gabriel, V., and Fontagné-Faucher, C. (2009). Biodiversity of lactic acid bacteria in French wheat sourdough as determined by molecular characterization using species-specific PCR. Int. J. Food Microbiol. 135, 53-59. doi: 10.1016/j.ijfoodmicro.2009.07.006

Roh, S. W., Kim, K. H., Nam, Y. D., Chang, H. W., Park, E. J., and Bae, J. W. (2010). Investigation of archaeal and bacterial diversity in fermented seafood using barcoded pyrosequencing. ISME J. 4, 1-16. doi: 10.1038/ismej.2009.83

Rubio, R., Jofré, A., Martín, B., Aymerich, T., and Garriga, M. (2014). Characterization of lactic acid bacteria isolated from infant faeces as potential probiotic starter cultures for fermented sausages. Food Microbiol. 38, 303-311. doi: 10.1016/j.fm.2013.07.015

Ruehmkorf, C., Ruebsam, H., Becker, T., Bork, C., Voiges, K., Mischnick, P., et al. (2012). Effect of structurally different microbial homoexopolysaccharides on the quality of gluten-free bread. Eur. Food Res. Technol. 235, 139-146. doi: 10.1007/s00217-012-1746-3

Salimnia, H., Alangaden, G. J., Bharadwaj, R., Painter, T. M., Chandrasekar, P. H., and Fairfax, M. R. (2011). Weissellaconfusa: an unexpected cause of vancomycin-resistant Gram-positive bacteremia in immunocompromised hosts. Transpl. Infect. Dis. 13, 294-298. doi: 10.1111/j.1399-3062.2010.00586.x

Samelis, J., Maurogenakis, F., and Metaxopoulos, J. (1994). Characterisation of lactic acid bacteria isolated from naturally fermented Greek dry salami. Int. J. Food Microbiol. 23, 179-196. doi: 10.1016/0168-1605(94)90051-5

Samelis, J., Rementzis, J., Tsakalidou, E., and Metaxopoulos, J. (1998). Usefulness of rapid GC analysis of cellular fatty acids for distinguishing Weissella viridescens, Weissella paramesenteroides, Weissella hellenica and some non-identifiable, arginine-negative Weissella strains of meat origin. Syst. Appl. Microbiol. 21, 60-65. doi: 10.1016/S0723-2020(98)80031-3

Santos, E. M., Jaime, I., Rovira, J., Lyhs, U., Korkeala, H., and Björkroth, J. (2005). Characterization and identification of lactic acid bacteria in "morcilla de Burgos." Int. J. Food Microbiol. 97, 285-296. doi: 10.1016/j.ijfoodmicro.2004.04.021

Sanz, Y., Sánchez, E., Marzotto, M., Calabuig, M., Torriani, S., and Dellaglio, F. (2007). Differences in faecal bacterial communities in coeliac and healthy children as detected by PCR and denaturing gradient gel electrophoresis. FEMS Immunol. Med. Microbiol. 51, 562-568. doi: 10.1111/j.1574-695X.2007.00337.x
Scheirlinck, I., Van der Meulen, R., Van Schoor, A., Vancanneyt, M., De Vuyst, L., Vandamme, P., et al. (2007). Influence of geographical origin and flour type on diversity of lactic acid bacteria in traditional Belgian sourdoughs. Appl. Environ. Microbiol. 73, 6262-6269. doi: 10.1128/AEM.00894-07

Schillinger, U., Boehringer, B., Wallbaum, S., Caroline, L., Gonfa, A., Huch Née Kostinek, M., et al. (2008). A genus-specific PCR method for differentiation between Leuconostoc and Weissella and its application in identification of heterofermentative lactic acid bacteria from coffee fermentation. FEMS Microbiol. Lett. 286, 222-226. doi: 10.1111/j.1574-6968.2008. 01286. $\mathrm{x}$

Schwab, C., Mastrangelo, M., Corsetti, A., and Gänzle, M. (2008). Formation of oligosaccharides and polysaccharides by Lactobacillus reuteri LTH5448 and Weissella cibaria 10M in sorghum sourdoughs. Cereal Chem. 85, 679-684. doi: 10.1094/CCHEM-85-5-0679

Sengun, I. Y., Nielsen, D. S., Karapinar, M., and Jakobsen, M. (2009). Identification of lactic acid bacteria isolated from Tarhana, a traditional Turkish fermented food. Int. J. Food Microbiol. 135, 105-111. doi: 10.1016/j.ijfoodmicro.2009.07.033

Serna-Cock, L., Vallejo-Castillo, V. E., and Garcia-Gonzalez, E. (2013). Effects of wall materials and lyophilization on the viability of Weissella confusa. African J. Biotechnol. 13, 2661-2667. doi: 10.5897/AJB2014.13860

Sharpe, M. E., Garvie, E. I., and Tilbury, R. H. (1972). Some slime-forming heterofermentative species of the genus Lactobacillus. 23, 389-397.

Shin, J. H., Kim, D. I., Kim, H. R., Kim, D. S., Kook, J. K., and Lee, J. N. (2007). Severe infective endocarditis of native valves caused by Weissella confusa detected incidentally on echocardiography. J. Infect. 54, 149-151. doi: 10.1016/j.jinf.2006.09.009

Shukla, S., Shi, Q., Maina, N. H., Juvonen, M., Maijatenkanen, and Goyal, A. (2014). Weissella confusa Cab3 dextransucrase: properties and in vitro synthesis of dextran and glucooligosaccharides. Carbohydr. Polym. 101, 554-564. doi: 10.1016/j.carbpol.2013.09.087

Sica, M. G., Olivera, N. L., Brugnoni, L. I., Marucci, P. L., López-Cazorla, A. C., and Cubitto, M. A. (2010). Isolation, identification and antimicrobial activity of lactic acid bacteria from the Bahía Blanca estuary. Rev. Biol. Mar. Oceanogr. 45, 389-397. doi: 10.4067/S0718-19572010000 300003

Silvester, M. E., and Dicks, L. M. (2003). Identification of lactic acid bacteria isolated from human vaginal secretions. Antonie van Leeuwenhoek 83, 117-123. doi: 10.1023/A:1023373023115

Sirirat, R., Thosaporn, R., and Somkiat, P. (2008). Evaluations of lactic acid bacteria as probiotics for juvenile seabass Lates calcarifer. Aquac. Res. 39, 134-143. doi: 10.1111/j.1365-2109.2007.01864.x

Skerman, V. B. D., McGowan, V., and Sneath, P. H. A. (eds.). (1989). Approved Lists of Bacterial Names, Amended Edition. Washington, DC: American Society for Microbiology.

Snauwaert, I., Papalexandratou, Z., De Vuyst, L., and Vandamme, P. (2013).Characterization of strains of Weissella fabalis sp. nov. and Fructobacillus tropaeoli from spontaneous cocoa bean fermentations. Int. J. Syst. Evol. Microbiol. 63, 1709-1716. doi: 10.1099/ijs.0.040311-0

Snyder, A. K., Hinshaw, J. M., and Welch, T. J. (2014). Diagnostic tools for rapid detection and quantification of Weissella ceti NC36 infections in rainbow trout. Lett. Appl. Microbiol. 60, 103-110. doi: 10.1111/lam.12365

Srionnual, S., Yanagida, F., Lin, L. H., Hsiao, K. N., and Chen, Y. S. (2007). Weissellicin 110, a newly discovered bacteriocin from Weissella cibaria 110, isolated from plaa-som, a fermented fish product from thailand. Appl. Environ. Microbiol. 73, 2247-2250. doi: 10.1128/AEM.02484-06

Stackebrandt, E., and Liesack, W. (1993)."Nucleic acids and classification,” in Handbook of New Bacterial Systematics, eds M. Goodfellow and A. G. O'Donnell (London: Academic Press Ltd), 151-194.

Švec, P., and Franz, C. M. A. P. (2014). "The genus Enterococcus," in Lactic Acid Bacteria, Biodiversity and Taxonomy, eds W. H. Holzapfel and B. J. B. Wood (Chichester: Wiley Blackwellpp), 175-211. doi: 10.1002/97811186552 52.ch15

Tajabadi, N., Mardan, M., Mustafa, S., Feizabadi, F., Nateghi, L., Rasti, B., et al. (2012). Weissella sp. Taj-Apis, a novel lactic acid bacterium isolated from honey. J. Food Agricul. Environ. 10, 263-267.

Tanasupawat, S., Shida, O., Okada, S., and Komagata, K. (2000). Lactobacillus acidipiscis sp. nov. and Weissella thailandensis sp. nov., isolated from 
fermented fish in Thailand. Int. J. Syst. Evol. Microbiol. 50, 1479-1485. doi: 10.1099/00207713-50-4-1479

Tanasupawat, S. I., Okada, S., and Komagata, K. (1998). Lactic acid bacteriafound in fermented fish in Thailand. J. Gen. Appl. Microbiol. 44, 193-200. doi: 10.2323/jgam.44.193

Thongsanit, J., Tanikawa, M., Yano, S., Tpachiki, T., and Wakayam, M. (2009). Identification of glutaminase-producing lactic acid bacteria isolated from Nham, a traditional Thai fermented food and characterisation of glutaminase activity of isolated Weissella cibaria. Ann. Microbiol. 59, 715-720. doi: 10.1007/BF03179213

Tieking, M., Korakli, M., Ehrmann, M. A., Ganzle, M. G., and Vogel, R. F. (2003). In situ production of exopolysaccharides during sourdough fermentation by cereal and intestinal isolates of lactic acid bacteria. Appl. Environ. Microbiol. 69, 945-952. doi: 10.1128/AEM.69.2.945-952.2003

Tingirikari, J. M., Kothari, D., and Goyal, A. (2014a). Superior prebiotic and physicochemical properties of novel dextran from Weissella cibaria JAG8 for potential food applications. Food Funct. 5, 2324-2330. doi: 10.1039/C4FO00319E

Tingirikari, J. M., Kothari, D., Shukla, R., and Goyal, A. (2014b). Structural and biocompatibility properties of dextran from Weissella cibaria JAG8 as food additive. Int. J. Food Sci. Nutr. 65, 686-691. doi: 10.3109/09637486.2014.917147

Tohno, M., Kitahara, M., Inoue, H., Uegaki, R., Irisawa, T., Ohkuma, M., et al. (2013). Weissella oryzae sp. nov., isolated from fermented rice grains. Int. J. Syst. Evol. Microbiol. 63, 1417-1420. doi: 10.1099/ijs.0.043612-0

Tohno, M., Kobayashi, H., Nomura, M., Uegaki, R., and Cai, Y. (2012). Identification and characterization of lactic acid bacteria isolated from mixed pasture of timothy and orchardgrass, and its badly preserved silage. An. Sci. J. 83, 318-330. doi: 10.1111/j.1740-0929.2011.00955.x

Tsakalidou, E., Samelis, J., Metaxopoulos, J., and Kalantzopoulos, G. (1997). Atypical Leuconostoc-like Weissella strains isolated from meat, sharing low phenotypic relatedness with the so far recognized arginine-negative Weissella spp. as revealed by SDS-Page of whole cell proteins. Syst. Appl. Microbiol. 20, 659-664. doi: 10.1016/S0723-2020(97)80039-2

Urso, R., Comi, G., and Cocolin, L. (2006). Ecology of lactic acid bacteria in Italian fermented sausages: isolation, identification and molecular characterization. Syst. Appl. Microbiol. 29, 671-680. doi: 10.1016/j.syapm.2006.01.012

Vahjen, W., Pieper, R., and Zentek, J. (2010).Bar-coded pyrosequencing of $16 \mathrm{~S}$ rRNA gene amplicons reveals changes in ileal porcine bacterial communities due to high dietary zinc intake. Appl. Environ. Microbiol. 76, 6689-6691. doi: 10.1128/AEM.03075-09

Vela, A. I., Fernández, A., de Quirós, Y. B., Herráez, P., Domínguez, L., and Fernández-Garayzábal, J. F. (2011). Weissella ceti sp. nov., isolated from beaked whales (Mesoplodon bidens). Int. J. Syst. Evol. Microbiol. 61, 2758-2762. doi: 10.1099/ijs.0.028522-0

Vela, A. I., Porrero, C., Goyache, J., Nieto, A., Sánchez, B., Briones, V., et al. (2003). Weissella confusa infection in primate (Cercopithecus mona). Emerg. Infect. Dis. 9, 1307-1309. doi: 10.3201/eid0910.020667

Vitali, B., Minervini, G., Rizzello, C. G., Spisni, E., Maccaferri, S., Brigidi, P., et al. (2012). Novel probiotic candidates for humans isolated from raw fruits and vegetables. Food Microbiol. 31, 116-125. doi: 10.1016/j.fm.2011.12.027

Walter, J., Hertel, C., Tannock, G. W., Lis, C. M., Munro, K., and Hammes, W. P. (2001). Detection of Lactobacillus, Pediococcus, Leuconostoc, and Weissella species in human feces by using group-specific PCR primers and denaturing gradient gel electrophoresis. Appl. Environ. Microbiol. 67, 2578-2585. doi: 10.1128/AEM.67.6.2578-2585.2001

Wang, C., Zhang, C. W., Chen, H. C., Yu, Q., Pei, X. F., and Liu, H. C. (2008). Phylogeny analysis and identification of two bacterial strains sourcing from human intestine and having resistance to acid and bile. Sichuan Da Xue Xue Bao Yi Xue Ban 39, 263-268.

Wang, J. P., Yoo, J. S., Jang, H. D., Lee, J. H., Cho, J. H., and Kim, I. H. (2011). Effect of dietary fermented garlic by Weissella koreensis powder on growth performance, blood characteristics, and immune response of growing pigs chal- lenged with Escherichia coli lipopolysaccharide. J. Anim. Sci. 889, 2123-2131. doi: $10.2527 /$ jas.2010-3186

Welch, T. J., and Good, C. M. (2013). Mortality associated with weissellosis (Weissella sp.) in USA farmed rainbow trout: potential for control by vaccination. Aquaculture 388-391, 122-127. doi: 10.1016/j.aquaculture.2013.01.021

Welch, T. J., Marancik, D. P., and Good, C. M. (2014). "Weissellosis," in AFS-FHS (American Fisheries Society-Fish Health Section). FHS Blue Book: Suggested Procedures for the Detection and Identification of Certain Finfish and Shellfish Pathogens, 2014 edition. 1.3.4, 1-10. Available online at: http://afs-fhs.org/bluebook/bluebook-index.php

Wolter, A., Hager, A. S., Zannini, E., Czerny, M., and Arendt, E. K. (2014). Influence of dextran-producing Weissella cibaria on baking properties and sensory profile of gluten-free and wheat breads. Int. J. Food Microbiol. 172, 83-91. doi: 10.1016/j.ijfoodmicro.2013.11.015

Wouters, D., Grosu-Tudor, S., Zamfir, M., and De Vuyst, L. (2013). Bacterial community dynamics, lactic acid bacteria species diversity and metabolite kinetics of traditional Romanian vegetable fermentations. J. Sci. Food Agric. 93, 749-760. doi: 10.1002/jsfa.5788

Wu, R., Wang, L., Wang, J., Li, H., Menghe, B., Wu, J., et al. (2009). Isolation and preliminary probiotic selection of lactobacilli from koumiss in inner Mongolia. J. Basic Microbiol. 49, 318-326. doi: 10.1002/jobm.200800047

Yanagida, F., Chen, Y. S., and Yasaki, M. (2007). Isolation and characterization of lactic acid bacteria from lakes. J. Basic Microbiol. 47, 184-190. doi: 10.1002/jobm.200610237

Yang, J., Ji, Y., Park, H., Lee, J., Park, S., Yeo, S., et al. (2014). Selection of functional lactic acid bacteria as starter cultures for the fermentation of Korean leek (Allium tuberosum Rottler ex Sprengel). Int. J. Food Microbiol. 191C, 164-171. doi: 10.1016/j.ijfoodmicro.2014.09.016

Yoshiyama, M., Wu, M., Sugimura, Y., Takaya, N., Kimoto-Nira, H., and Suzuki, C. J. (2013). Inhibition of Paenibacillus larvae by lactic acid bacteria isolated from fermented materials. Invertebr. Pathol. 112, 62-67. doi: 10.1016/j.jip.2012.09.002

Zambou, N. F., Sieladie, D. V., Fonteh, F. A., Moundipa, P. F., Tchouanguep, F. M., and El Soda, M. (2008). Phenotypic characteristics of lactic acid bacteria isolated from cow's raw milk of Bororo Cattle breeders in Western Highland Region of Cameroon. Res. J. Microbiol. 3, 447-456. doi: 10.3923/jm.2008.447.456

Zamudio-Maya, M., Narváez-Zapata, J., and Rojas-Herrera, R. (2008). Isolation and identification of lactic acid bacteria from sediments of a coastal marsh using a differential selective medium. Lett. Appl. Microbiol. 46, 402-407. doi: 10.1111/j.1472-765X.2008.02329.x

Zannini, E., Mauch, A., Galle, S., Gänzle, M., Coffey, A., Arendt, E. K., et al. (2013). Barley malt wort fermentation by exopolysaccharide-forming Weissella cibaria MG1 for the production of a novel beverage. J. Appl. Microbiol. 115, 1379-1387. doi: $10.1111 /$ jam.12329

Zhang, Z., Peng, X., Zhang, N., Liu, L., Wang, Y., and Ou, S. (2014). Cytotoxicity comparison of quercetin and its metabolites from in vitro fermentation of several gut bacteria. Food Funct. 5, 2152-2156. doi: 10.1039/C4FO00418C

Zhao, Z. G., Quan, W. R., Li, G. H., An, C. M., and Cui, Y. X. (2008). The isolated strains from kimchi and its use in semi-dry fermented sausage. Chinese Food Sci. Technol. 5, 11-13.

Conflict of Interest Statement: The authors declare that the research was conducted in the absence of any commercial or financial relationships that could be construed as a potential conflict of interest.

Copyright (C) 2015 Fusco, Quero, Cho, Kabisch, Meske, Neve, Bockelmann and Franz. This is an open-access article distributed under the terms of the Creative Commons Attribution License (CC BY). The use, distribution or reproduction in other forums is permitted, provided the original author(s) or licensor are credited and that the original publication in this journal is cited, in accordance with accepted academic practice. No use, distribution or reproduction is permitted which does not comply with these terms. 